THINKING THIRD SECTOR IN CANADIAN AND GERMAN SETTLEMENT AND SOCIAL INCLUSION

by

Riley Rose Bushell, BA, University of British Columbia, 2014

\author{
A Major Research Paper \\ presented to Ryerson University \\ in partial fulfillment of the requirements for the degree of \\ Master of Arts \\ in the Program of \\ Immigration and Settlement Studies
}

Toronto, Ontario, Canada, 2018

(C) Riley Bushell, 2018 

(MRP)

I hereby declare that I am the sole author of this Major Research Paper. This is a true copy of the MRP, including any required final revisions, as accepted by my examiners.

I authorize Ryerson University to lend this MRP to other institutions or individuals for the purpose of scholarly research.

I further authorize Ryerson University to reproduce this MRP by photocopying or by other means, in total or in part, at the request of other institutions or individuals for the purpose of scholarly research.

I understand that my MRP may be made electronically available to the public. 


\title{
THINKING THIRD SECTOR IN CANADIAN AND GERMAN SETTLEMENT AND SOCIAL
} INCLUSION

\author{
Riley Rose Bushell \\ Master of Arts 2018 \\ Immigration and Settlement Studies \\ Ryerson University
}

\begin{abstract}
Canada and Germany have become major immigrant-receiving countries of the Global North, sharing settlement structures shaped by federal, regional and municipal governments and operated by large and diverse third sectors. Through an integrative literature review, this study critically examines the Canadian and German third sectors involved in settlement and social inclusion initiatives, particularly in the context of neoliberal policymaking prevalent in both countries since the 1980s. First outlining the structure and landscape of settlement in each country, it identifies several shared challenges stemming from neoliberal federal policy and the retreat of the national welfare state. Filling literature gaps in this field is particularly important given recent increases in asylum-seeking in Germany, and the global emergence of right-wing, anti-immigration political movements. The purpose of this study is to serve as the basis for further cross-national consideration, discussion and mutual learning between Canada and Germany.
\end{abstract}

\section{Key words:}

Canada, Germany, third sector, settlement sector, social inclusion, asylum, immigration, neoliberal policy and restructuring 


\section{ACKNOWLEDGEMENTS}

Much of this Major Research Paper (MRP), as well as the graduate program for which it serves as a capstone, has taken place in Toronto, Ontario. Toronto is in the 'Dish With One Spoon Territory,' named for a treaty between the Anishinaabe, Mississaugas and Haudenosaunee that bound them to share the territory and protect the land. Subsequent Indigenous Nations and peoples, Europeans and all newcomers have been invited into this treaty in the spirit of peace, friendship and respect. My studies this year have reaffirmed that any work alongside immigrants and refugees in Canada must be rooted in an acknowledgement of Indigenous heritage and their continued presence on these ancestral lands.

Part of this MRP also took place in Osnabrück, Germany, through an academic exchange facilitated by Ryerson's Immigration and Settlement Studies (ISS) graduate program and the University of Osnabrück's Institute for Migration Research and Intercultural Studies (IMIS). I'd like to thank ISS program director Dr. Harald Bauder for assisting to coordinate this exchange, and Dr. Antonie Schmiz as well as many of her colleagues for graciously hosting me at IMIS. I am so grateful for this unique opportunity, which was also made possible through a MITACS Globallink Research Grant.

Thank you to my supervisor, Dr. John Shields, for sparking my interest in the third sector, and for his kind support and encouragement ever since. His mentorship and broader body of work demonstrates the value of solidarity between Canadian academics and the vibrant newcomer communities that enrich this country. I'd like to express my gratitude to my second reader, Dr. Bryan Evans, for his key role in this process. I count myself very lucky for the guidance of two such experts in this fascinating field.

Additional gratitude to my fabulous cohort, whose friendship, support and solidarity has been a highlight of the graduate experience. I'd lastly like to thank my parents, Carla and Tim, and my sisters, Shelby and Elena, for their endless, wholehearted love throughout all of my adventures, academic and otherwise. 
Table of Contents

AUTHOR'S DECLARATION FOR ELECTRONIC SUBMISSION OF AN MRP...................ii

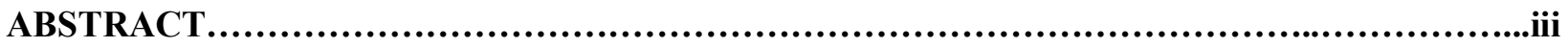

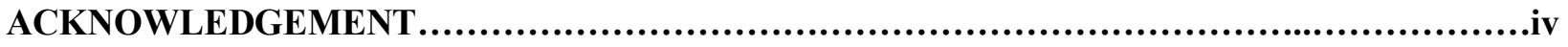

INTRODUCTION...................................................................................

CHAPTER 1: Methodology and Approach.........................................................

CHAPTER 2: Settlement and Social Inclusion in Canada.......................................10

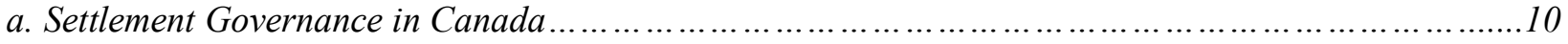

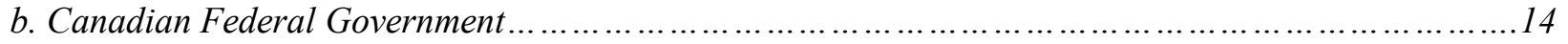

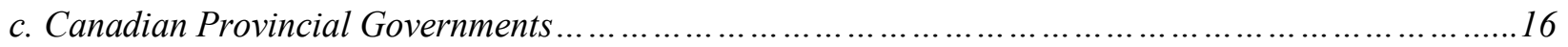

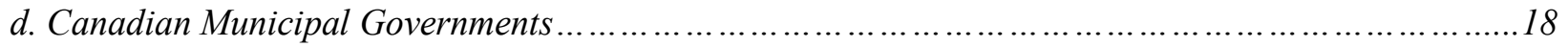

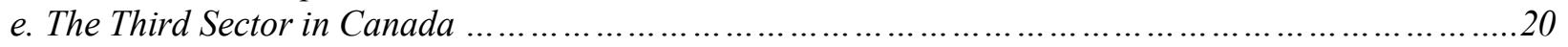

CHAPTER 3: Themes in Canada's Third Sector in Settlement....................................23

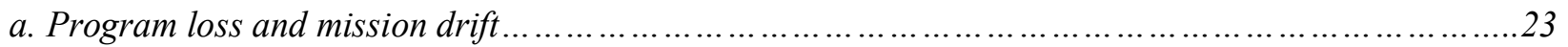

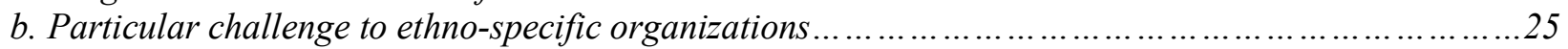

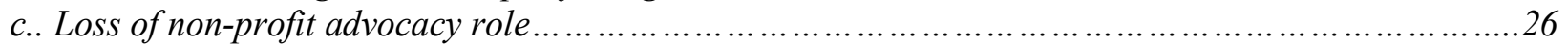

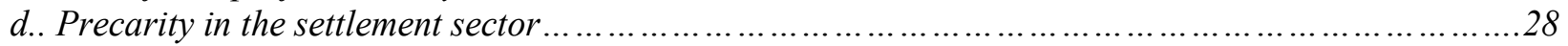

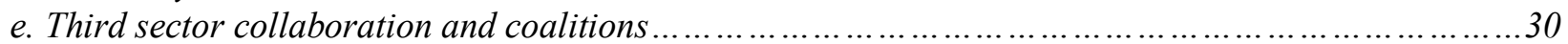

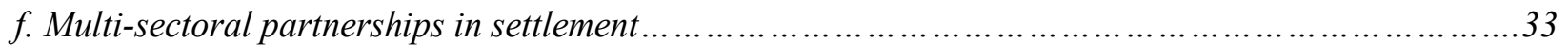

CHAPTER 4: Settlement and Social Inclusion in Germany .......................................36

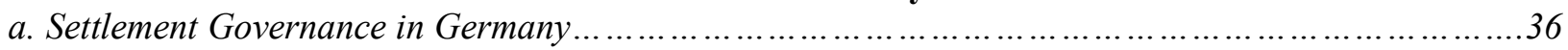

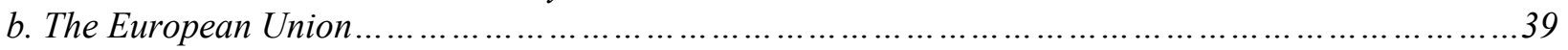

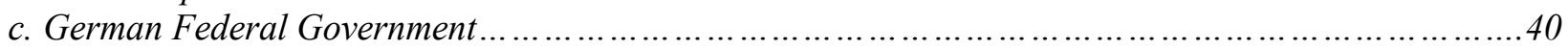

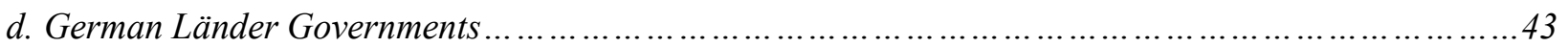

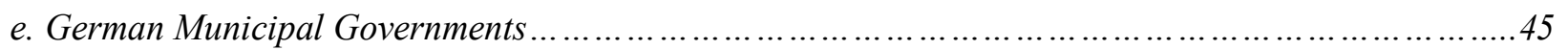

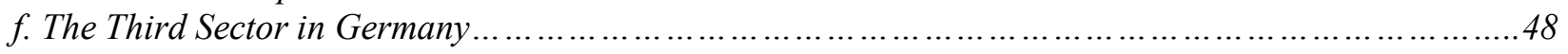

CHAPTER 5: Themes in Germany's Third Sector in Settlement and Cross-National

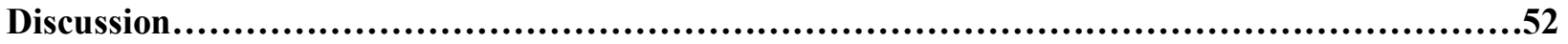

a. Neoliberalism, devolution and "responsibilization" in the third sector .................................52

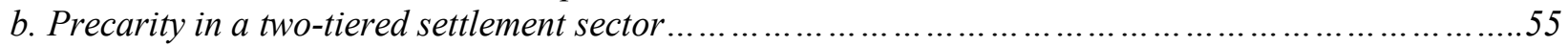

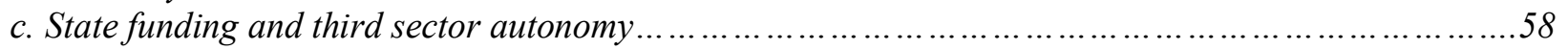

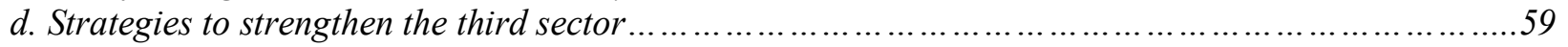

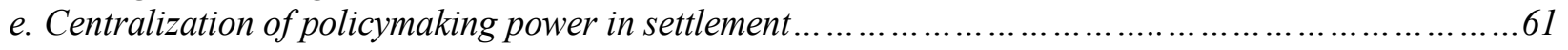

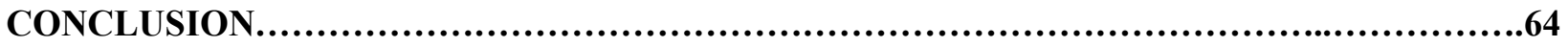

REFERENCES...........................................................................67 


\section{Introduction}

Immigration and settlement are etched into the social, political and cultural geographies of Canada and Germany in patterns as deep as they are distinct. Canada was shaped by immigration long before confederation, as British and French settlement dispossessed Indigenous populations and expanded colonial geographies. In the same time frame, the German Empire's industrial era was fueled by immigrant inflows. The first half of the $20^{\text {th }}$ century in Canada was marked by Eurocentric and racially discriminatory immigration policymaking (Kelley and Trebilcock 2010), while Germany became the apex of displacement and forced migration through two World Wars. Despite geographic, historical and political differences, Triadafilopoulos finds that in both countries "exclusion based on race and ethnicity" reinforced and reflected ethno-nationalism in this era $(2004,385)$. In both countries, too, postwar economic booms expanded the admission of foreign-born workers. In Canada, immigration processes became increasingly transparent and, following the implementation of the 1967 Points System, newcomers were admitted for the first time on the basis of their education, training and skills rather than country of origin (Kelley and Trebilcock 2010). During this time, Germany also relied on Gastarbeiter, guest workers from Southern Europe, the Balkans, Turkey and Northern Africa, to serve as "economic 'shock absorbers"' by filling labour demand (Bauder 2008, 59). The late $20^{\text {th }}$ century was marked by increasing ethno-cultural diversity in Canada and Germany, due both to labour flows and the increasing entry of asylum-seekers fleeing war and persecution from Latin America to the Soviet Union.

Today, Canada and Germany are among the Global North's foremost immigrant and refugeereceiving countries. Though Conservative politicians long insisted Germany was 
Nichteinwanderungsland or "not an immigration country," landmark legislation in the early 2000s signaled federal recognition of immigration as vital to economic growth (Bauder 2008, Kohlmeier et al. 2005). Canada's 2016 Census found that more than one in five residents are foreign-born (Statistics Canada 2017), and in this light Immigration Minister Ahmed Hussain recently cited their contribution to "economic growth, job creation and prosperity" as the rationale behind a new plan to admit almost one million newcomers over the next three years (Government of Canada 2017). Following Trudeau's election, the mobilization of resources to welcome 25,000 Syrians signaled federal commitment to refugee resettlement, though our experience in this realm pales in comparison to that of Germany. Since the early 2010s, Germany's intake of asylum-seekers fleeing war-torn Syria and conditions of violence, political instability and poverty in the Balkans, the Middle East and across Africa has grown to unseen heights. Germany became the vanguard of refugee movement in Europe when Chancellor Angela Merkel suspended the Dublin Convention for Syrian asylum-seekers in 2015, processing over 722,000 first-time asylum requests the following year. Germany also recognized asylum at the highest rate across the EU, granting protection to nearly 575,000 asylum-seekers between 2015 and 2017 (Eurostat 2017).

For newcomers in Canada and Germany, migration is the first step of a much longer journey in resettlement. Richmond and Shields note that this a complex, uneven process that often extends into multiple generations, but divide it generally into three stages (2005). In the first, immediate needs of information and referral, language and training and short-term shelter are met. Next, a newcomer must secure access to "appropriate employment and housing, education and so forth... for all members of the newcomers' families" (Richmond and Shields 2005, 515). The final phase is the most challenging, in 
which "newcomers develop some sense of attachment or belonging... without giving up their ethno-racial identities or their ties to the homeland" (Richmond and Shields 2005, 515). Valenzuela et al. similarly describe settlement as phases of "1) adjustment, where newcomers become acclimatized to their new country, culture, language and environment, so they can adjust and cope with their new situation, 2) adaptation, which involves deeper learning and managing their new situation without need for high levels of assistance; and, 3) integration, which constitutes immigrants' ability to actively and meaningfully participate in society and contribute as full citizens of their new country" $(2018,68)$. These phases can be overlapping or non-sequential, and are experienced distinctly for each individual.

In the final stages of settlement, immigrants and asylum-seekers gain social inclusion, described by Richmond and Omidvar as "full and equal participation in the economic, social and cultural and political dimensions of life in their new country" $(2003,1)$. For Lo et al., social inclusion concerns "the barriers or access people encounter in their attempts to gain a share of society's resources" $(2010,2)$, though Papillion notes that it also encompasses "the degree to which immigrants participate in the daily life of their community, neighborhood and society more broadly" (2002, 5). According to Omidvar and Richmond, social inclusion is "both a process and a goal," requiring "investments and action" from a variety of stakeholders in settlement $(2003,2)$. Government actors in Canada and Germany include the federal, regional or provincial and municipal tiers. In Germany, an additional supranational entity- the European Union (EU) - also frames decision-making in settlement. While this Major Research Paper (MRP) will frame newcomer social inclusion in the roles of these key public actors, they are well-profiled elsewhere and will not be its primary subject. Instead of adopting the governmental perspective, this study 
seeks to re-examine settlement from the bottom-up through the lens of institutions rooted in newcomer communities at the local level.

M. Salamon and S. Wojciech Sokolowski of the Johns Hopkins Center for Civil Society Studies, among the world's foremost experts in third sector studies, note that the concept of a sphere beyond the state and market "is probably one of the most perplexing concepts in modern political and social discourse," both due to its "tremendous diversity" and its being a relatively recent area of study (2016, 1515). With organizational mandates that do not relate to profit-making, this sphere is variously referred as the "civil society sector, non-profit sector, voluntary sector, charitable sector, third sector... social economy, social enterprise, and many more" (Salamon and Sokolowski 2016, 1521). Yet, at their core, Evans and Shields note that third sector institutions simply share mandates of "philanthropy, altruism, charity, reciprocity, mutuality" $(2000,3)$. The third sector is often defined in relation to government, and Dennis Young notes that it is mainly conceived a) as a supplement to the state, "fulfilling the demands for public goods left unsatisfied by the government," b) as a complement to the state via service-delivery partnerships or contractual funding arrangements and c) as an adversary engaged in mechanisms of mutual accountability $(2000,168)$. For him, these "multilayered" relationships are not mutually exclusive, but best understood as a "composite of views" (Young 2000, 168). Yet, there are also more abstract structures that influence the third sector. Olaf Corry cites Michael Foucault's theory of governmentality as "an interconnected system of discourse and techniques or institutions that allow certain practices to flourish and other to appear impossible, wrong or just ludicrous" $(2010,16)$. In other words, power extends beyond the political sphere and is equally embedded in society's economic and moral paradigms. 
In this light, Corry notes that "the third sector is not to be taken at face value as a power-free zone of noncoerced realization of shared values..." but rather as "part of power technologies through which a certain kind of governance is achieved" $(2010,16)$. In "re-conceptualizing the third sector," Salamon and Sokolowski also find this sphere influenced by social norms and values, and Garkish et al. note the usefulness of this understanding in cross-national comparisons of "the great variety or organizational actors" as well as the host societies that shape national migration and settlement paradigms $(2016,1515)$.

With these terminological considerations in mind, the purpose of this MRP is to provide a critical and comparative review of immigrant and refugee settlement as pertains to the third sector role in Canada and Germany. Despite contrasting politics, geographies and histories, Canada and Germany demonstrate "striking similarities" as home to large, diverse third sectors active in newcomer social inclusion (Bauder and Jayaraman 2014, 181). In both countries, too, the third sector has been shaped by neoliberal political and socio-economic paradigms that have framed government decision-making since the 1980s. Given their similar profiles as immigrant and refugee-receiving countries, many note the suggestion that Canadian settlement initiatives serve as a blueprint for Germany (Triadafilopoulos 2004; Bauder et al. 2014). Yet, Richmond and Shields warn against exporting a "romantic and idealized model" without critically examining the experience of the Canadian third sector in the context of neoliberal policy (2005, 522). Taking a cue from Bauder, my research also "challenges the analytical lens that knowledge should only transfer from Canada to Germany," and suggests that we consider "what Canada can learn from Germany's vast experience with immigrants, refugees and guest workers" (2014, 3). In this MRP, I will outline the development of Canada's third sector in settlement and social inclusion before discussing 
findings related to its structure and landscape in the neoliberal context. After similarly exploring the German case, I will identify and discuss cross-national themes, commonalities and divergences.

This research is a valuable resource for a range of stakeholders invested in social inclusion in Canada and Germany. As Garkish et al. note, "the capability of politicians, practitioners and organizations to implement adequate solutions...strongly depends on available knowledge..." (2017, 1842). It also fills an existing literature gap. German and Canadian governments involvement in migration and settlement have been cross-nationally profiled (Triadafilopoulos 2004; Bauder et al. 2014; Korntheuer et al. 2017; Alba and Foner 2014), but as Siemiatycki and Triadafilopoulous note, the third sectors in both countries "have garnered far less scholarly and media attention" $(2010,2)$. Yet, as they argue, settlement services provided by the third sector are "not simply a technocratic, administrative or academic exercise" but rather reflect "the host society's belief of the place of foreigners in their midst, and more broadly the role of government in civil society" (Siemiatycki and Triadafilopoulos 2010, 21). Menz also notes that the role of non-state actors is "commonly neglected" in migration literature $(2011,438)$. For Garkish et al., this literature gap is particularly "striking" in the context of modern migrant and refugee movement across Europe, as "little is known about the systematic relationship between the variety of third sector organizations and the many faces of migration and its challenges" $(2017,1842)$. By addressing this gap, this project aims to enrich future research and enhance knowledge transfer between Canada and Germany, particularly in examining settlement and social inclusion from a third sector perspective. The imagined outcome is that each country can learn from best practices of the other, and from common challenges that each of them face. 


\section{Chapter 1: Methodology and Approach}

As global population movement both responds to and prompts geopolitical, economic and social upheaval on a daily basis, scholars of migration and settlement must produce relevant and accurate work at a rapid pace. Yet, Russell also notes that "as specialization increases and the volume of completed research expands, scholars are constantly challenged to possess an accurate and current understanding" of the matter at hand $(2005,8)$. For these reasons, according to Neumann, the integrative literature review is an essential academic aid in "presenting and summarizing the current state of knowledge on a topic," distilling central themes and frameworks, highlighting points of contestation and identifying avenues for further research $(2006,112)$. Russell notes that an integrative literature review can also be comparative in nature, working to "build a bridge between related areas of work" $(2005,8)$. For Alba and Foner, examining migration through this comparative lens helps to "shed light on the "invisible" - the systemic features of each society that, because they are national 'constants,' are often overlooked or taken for granted in a single country analysis" $(2014,266)$. Shields et al. note that because Canadian immigration and settlement policies are often celebrated as best practice, we have failed to consider "innovative policies from elsewhere," and that comparative studies help to "illuminate larger structural, political and other factors" that shape our outlook in this sphere (Shields et al. 2016, 24). Similarly, for Bloemraad, a comparative approach to newcomer settlement highlights that "the societies in which immigrants reside have as much or even more influence on the processes of ...immigrant incorporation than the characteristics of those who move" $(2013,33)$. Focusing particularly on the influence of a neoliberal policy context, my MRP will collect, compare and critique available literature on the Canadian and German third sectors through an integrative literature review. 
There are clear challenges in conducting an effective integrative literature review regarding nation states with distinct histories and geopolitics, exacerbated by my outsider status as an Englishspeaking, Canadian-born researcher. Russell warns that omission of important details "could affect the... information about the relationships between variables under study" $(2005,12)$, and Bloemraad suggests that researchers avoid such "pitfalls" by carefully considering how each case study "advances the project" at hand $(2013,30)$. In recent international comparative studies of the third sector in settlement, both Shields et al. (2016) and Garkish et al. (2017) also note limited availability of English-language information. Yet, by adopting flexible design, both were able to produce rich and valuable cross-national studies on which I will rely as examples for my own qualitative research. To be clear, the aim of this MRP is not to evaluate national performance in settlement, but to identify and discuss best practices and shared challenges through the lens of the third sector. With these methodological considerations in mind, this MRP will review relevant, recent English-language literature including journal articles, books, government documents, and gray scholarship produced within the third sector itself. Methods of information retrieval include Ryerson University Library and Archives, Google Scholar and the Institute for Migration and Intercultural Studies Library at the University of Osnabrück. Key search terms include "migration/settlement/integration and the third sector/non-profits in Canada, and migration/settlement/integration and the third sector/non-profits in Germany."

For Amartya Sen, human rights are "an assertion of the importance of freedoms" that mediate one's capacity to engage with the world $(2004,321)$. Such freedoms are founded on "capability" defined as "the opportunity to achieve valuable combinations of human functioning" (Sen 2004, 332). For 
example, Sen considers "the freedom of new immigrants...to conserve the ancestral cultural customs and life-styles from their country of origin" $(2004,335)$. Capability is "the freedom to choose how [one] should live, including the opportunity to pursue ancestral customs" to the extent of one's choosing within legal bounds $(2004,336)$. The capability approach ties to social inclusion frameworks, as both underscore active space-making in the economic, social, cultural and political spheres of a host society. Within qualitative social science, Neumann outlines a critical tradition which recognizes that "knowledge is power" which upholds research as "a moral, political activity" $(2006,100)$. To this end, this MRP suggests that all stakeholders in settlement benefit where newcomer capabilities are expanded as far as possible through social inclusion, that third sector settlement services play a key role in this process and that research should actively support this expansion. Through this methodology and approach, my MRP aims to answer the following questions:

- What is the structure and landscape of the third sector in Canadian settlement services?

- What is the structure and landscape of the third sector in German settlement services?

- How has the third sector in Canada and Germany responded to unique challenges and policy constraints?

- What can be learned in a comparative study of available literature regarding the role and responsiveness of the Canadian and German third sectors in settlement and inclusion? 


\section{Chapter 2: Settlement and Social Inclusion in Canada}

While the focus of this paper is the third sector, their role in settlement and social inclusion is inextricably tied to shifting tides of government policy and practices. To better understand Canada's settlement sector requires briefly addressing the role of federal, provincial and municipal governments in this sphere. In particular, such actors must be contextualized within the neoliberal shift that has characterized Canadian settlement policy since the late 1980s. As Morris notes, this political, economic and social doctrine has become "the basis for most governmental decision-making in Canada" $(1997,25)$, shaping both settlement services and third sector agencies increasingly responsible for their provision.

\section{a. Settlement Governance in Canada}

In the 1950s, inspired by philosophies of British economist John Maynard Keynes, governments across North America took action to address unemployment and economic stagnation (Morris 1997). Evans et al. refer to the "Keynesian" system as one in which comprehensive social services were provided by Canada's welfare state from the 1950 s to the 1980 s $(2005,77)$. Third sector agencies were key service providers during this time, but operated in a "mixed social economy" strengthened by mutual support, interdependence with the government and growth "in tandem" (Evans et al. 2005, 75). Under this system, Evans et al. characterize the state and third sector relationship as one in which:

"1) funding was provided by the state that was... primarily base or core funding, allowing for significant latitude in spending purposes; 2) funding was long term and stable, which allowed [nonprofit organizations] to build institutions that became embedded in communities; 3 ) the relationships between the state and NPOs tended to be regulated by bonds of trust, not highly regulated contracts, which awarded non-profits considerable autonomy in how they constructed and delivered programs supported by public funds; 4) the role of NPO service providers was not to replace/displace state provided public goods, but to fill gaps complementing Keynesian welfare state measures and 5) a system of adhocracy, rather than rigid forward planning regulation, tended to govern the evolution of the relationship between the state and NPOs" (Evans et al. 2005, 76). 
However, an aging workforce, growing government deficits and increasing global competition diminished federal willingness to spend on Canadian social services. By the late 1980s, Morris notes that debt became "terrifically serious," totalling 100 percent of the country's economic output (Morris 1997, 26). Neoliberal public policy was implemented to address these issues, in particular through the "cutting of public expenditure for social services...; deregulation of government activities that might diminish profits ... and privatizing government-run businesses" (Morris 1997, 25). As an economic, social and moral doctrine, such neoliberal public policies replaced the Keynesian concept of "the public good" with an ethos of self-reliance and individual responsibility (Morris 1997, 25).

Evans and Shields note that, under the assumption that civil society is "entirely self-sustaining" and made less effective by government intervention, some envision a "positively rosy" future for Canada's third sector in the neoliberal context $(2000,9)$. Yet, many remain critical of these changes. According to Arat-Koc, the government essentially began "emphasizing selection of immigrants to maximize their economic contribution... while minimizing any costs in their settlement and welfare" $(1999,49)$. For Shields, this "shredded the Keynesian social contract" as the retreating welfare state eroded settlement services among other social services traditionally upheld by the Canadian government (2004, 2). Similarly, Acheson and Laforet find that upper-tier governments used "hard power" to establish neoliberal policy "by destroying the funding relationship on which the old regime had rested and ignoring the furious protests of organized interests in civil society" $(2013,609)$. Lowe et al. note that third sector settlement organizations depend on government funding for "over 85 percent" of overall budgets (2017, 25), and for this reason defunding and austerity have affected their capacity to support newcomer clients 
through the resettlement process. For example, Sadiq recalls that federal cutbacks in the late 1990s drastically reduced "the number, range, and breadth of newcomer services" (2004, 13). Cutbacks were also implemented at a provincial level. In Ontario, for example, Conservative Premier Mike Harris established funding cuts in settlement services as well as equity and anti-racism programming following his election in 1995. By 1996, Sadiq notes that "approximately 43 per cent of all programs for immigrants and refugees were at a high risk of being eliminated" $(2004,13)$. Though the province gained additional funding through the Canada-Ontario Immigration Agreement (COIA) in 2005, Lowe likens these funds to "building the sector out of a house of cards" in that little planning had been done to stabilize the sector following its expiry in $2011(2017,26)$. According to Kilbride, in Ontario and across Canada, "the marked deterioration of funding" in the 1990s has not yet been fully remedied, and "much less have new issues been adequately funded" (2009, iii).

Evans et al. note that neoliberal cost-cutting in settlement and across Canadian social services was largely based on the reasoning that "government should steer (focus on policy setting and coordination) and leave the rowing (the delivery of publicly supported services) as much as possible to other parties" $(2005,77)$. This model has been achieved through devolution, defined by Arat-Koc as "a process whereby the federal government divests itself of deficits and downloads social programmes and fiscal responsibilities" to lower levels of governance $(1999,48)$. In Canada, the 1995 Settlement Renewal policy devolved responsibilities in settlement to the provinces via federal-provincial settlement agreements. To some extent, devolution can introduce innovation into settlement policy by localizing settlement programmes. For example, McGrath and McGrath praise the former Canada-British Columbia Immigration Agreement as "a model of devolution," in which federal funders transferred payments to the province who designed, delivered, administered and evaluated province-specific programming $(2013,6)$. 
However, Siemiatycki and Triadafilopoulous note that "devolution should never be an end in and of itself, but a means of strengthening immigrant settlement and integration" and must always be attached to appropriate funding $(2010,6)$. As Settlement Renewal was enacted at the federal level, Mukhtar et al. note that the Canadian government was "simultaneously cutting funding for immigrant services throughout the provinces" $(2016,391)$, which increasingly became the prerogative of municipalities, third sector organizations and newcomer communities (Acheson and Laforet 2013; Baines et al. 2014; Evans and Shields 2000). Yet, Evans and Shields argue that "as the state recedes it does not wither away but rather a 'shadow state' emerges to fill its void” $(2000,18)$. In the context of unfunded devolution, Canada's third sector has emerged as this "shadow state," delivering services formerly financed and coordinated by the Canadian government (Evans and Shields 2000, Sadiq 2004; Stasiulus et al. 2011).

Though the delivery of settlement services in Canada has devolved significantly to the third sector and newcomer communities themselves, Evans and Shields note that upper-tier governments have remained "at the centre and apex" of decision-making processes $(2000,16)$. Accompanying Settlement Renewal came a new paradigm for governing the third sector called New Public Management, which Lowe et al. characterize as a "transmission belt" for neoliberalism in Canadian settlement (2017, 19; Shields and Evans 1998). In contrast to comprehensive core funding and flexibility in spending under Keynesian public policy, NPM regulates third sector service provision through competitive, short-term government contracts held in place through strict accountability measures (Baines et al. 2014). As Neudorf notes, these contracts "prioritize direct service provision" over broader advocacy initiatives or sectoral support $(2016,95)$. Though this model employs the language of partnerships and mutual accountability, many argue that this structure disproportionately favours the funder agenda. For example, Sadiq notes that "the government... exercises a fair amount of social control over NGOs, because contract requirements and regulatory provisions specify which services will be funded" $(2004,4)$. For Evans et al., "the benign language of partnership hides a steeply hierarchical and centralized relationship of power" embedded in third-sector state contracts $(2005,78)$. State control has been extended through "centralized 
decentralization," as "market-based contracts and managerialist outcomes structures" became the backbone of Canada's settlement sector (Evans et al. 2005, 88).

\section{b. Canadian Federal Government}

Though Section 95 of the Canadian constitution denotes immigration and settlement joint federalprovincial responsibilities, federal legislation overrides that of individual provinces (Nijboer 2010,9). Prior to the 1950s, Bloemraad notes that federal immigration officials "focused on recruiting, processing and screening would-be immigrants rather than on settlement" $(2005,119)$. However, recognition of the role of immigrant labour in Canada's postwar economy strengthened their interest in this sphere, and under the Department of Citizenship and Immigration the government established settlement aid oriented towards working age males (Bloemraad 2005, 119). In the 1970s, under the new Department of Manpower and Immigration, the Canadian government began offering more comprehensive settlement services, including information and referral services, employment counselling, interpretation, translation and health supports (Biles et al. 2011, 199). To cover this broadened field, the federal government began funding third sector organizations as primary service deliverers (Shah 2014, 18). Today, Canada's federal office operates as Immigration, Refugees and Citizenship Canada (IRCC). While IRCC maintains policymaking power in immigration and settlement, they still rely on third sector organizations to delivery settlement services locally. Leo and August term this system "deep federalism" whereby, at least in theory, "national government policies are formulated and implemented with sufficient flexibility to ensure their appropriateness to different conditions in different communities" $(2009,491)$. IRCC views settlement through the lens of a "two-way street," in which newcomers to Canada are "expected to take ownership" by accessing the labour market, tapping available support and abiding by Canadian law $(2017,4)$. According to IRCC, the role of Canadian institutions is to "ensure there are inclusive laws/policies and enabling programs in place to promote inclusion for all permanent residents and citizens," including an effective array of settlement services $(2017,4)$. 
As the primary federal agency responsible for settlement initiatives, IRCC supports immigrants and refugees through a broad array of programs and funding. The Resettlement Assistance Program (RAP) is a funding stream exclusive to government-assisted refugees (GARs), who are provided the equivalent of social assistance rates for up to one year. According to Nakhaie, this funding is meant to "bridge GARs into Canadian society, help them pay for transportation loans... learn English or French and segue into the labour market" $(2017,13)$. However, due to Canada's high cost of living, lack of language skills and financial resources, refugees in Canada are often forced to rely on other settlement services and forms of welfare (Nakhaie 2017, 13). Until 2008, IRCC settlement programs targeting all newcomers included the Immigrant Settlement and Adaptation Program (ISAP), which focussed on reception, referral, orientation and interpretation and the Language Instruction for Newcomers in Canada (LINC) program, which provided basic language training in English or French. The Host Program provided additional funding to train volunteers in helping newcomers adapt to life in Canada (Lim et al. 2005, 6). In 2008, IRCC implemented a "Modernized Approach" to settlement and integration by consolidating these three funding streams into a single Settlement Program, which also introduced multiyear funding contracts for third sector service deliverers (Neudorf 2016). In 2017/18, IRCC has committed to an investment of over $\$ 690$ million in funding over 500 organizations across Canada beyond Quebec. Over \$345 million in federal funds flowed through Quebec's Ministère de l'immigration et des communautés culturelles (MICC), which under the 1991 Canada-Quebec Accord operates with greater provincial autonomy in immigrant selection and settlement.

Though federal funds are a major source of third sector funding in Canada, not all immigrants and refugees are eligible for federally-funded programs nor do they cover all essential settlement services. For the most part, only permanent residents are eligible for IRCC settlement funding. Temporary foreign workers, international students, asylum claimants without status and Canadian citizens are ineligible for IRCC-funded programs. On one hand, Ashton et al. note that IRCC's policy position is "based upon the premise that Canada has no commitment to supporting migrants until they become permanent 
residents... and that the Canadian taxpayer would not support providing extensive settlement services to those who may only stay in Canada a limited time" $(2016,75)$. However, eligibility requirements exacerbate the unique social exclusion of certain newcomer cohorts including short-term foreign workers, international students and asylum claimants, who often enter Canada with relatively less resources to attend language classes, seek accreditation or legal support. In Ashton et al.'s 2016 study, third sector respondents compared eligibility requirements to "segregation between immigrants who could access IRCC funded services and "others" (76). Literature suggests that such requirements are burdensome for many newcomers in Canada, as well as the third sector agencies that serve them. In Mukhtar et al.'s study of Peel-region ISAs, one reported $80 \%$ of clients inquiring about federally-funded English classes as ineligible $(2016,399)$. Given their reliance on government funding, Papillion notes that organizations are "faced with a difficult dilemma between refusing such clients, despite their obvious need, or providing services without receiving the financial resources to do so" $(2002,17)$. Beyond issues in eligibility, Richmond and Shields find that IRCC funding focusses on the first stages of settlement, including “information and referral, language training, short-term shelter etc." $(2005,515)$. Similarly, according to Papillion, services funded by the federal government "do not include essential long-term settlement services such as community development initiatives, access to programs for housing, health and other social services or market-oriented skills development programs" $(2002,17)$.

\section{c. Canadian Provincial Governments}

In Canada, provincial ministries are responsible for providing a range of services for both newcomers and Canadian-born residents. For example, Biles et al. note that in Ontario, the former Ministry of Citizenship and Immigration, Municipal Affairs and Housing, Children and Youth Services, Community and Social Services, Culture, Education, Labour, Economic Development and Trade provided key programming for newcomer residents $(2011,212)$. Yet, provinces have actively negotiated their own unique roles in immigration and settlement. The 1991 Canada-Quebec Accord was the first and most comprehensive formal federal-provincial agreement in this field, and as Reichhold notes that this 
legislation gave Quebec “enviable” exclusive powers in both immigrant selection and settlement (2010, 39). In the late 1990s and early 2000s, Manitoba, British Columbia, Saskatchewan, New Brunswick, Newfoundland and Labrador, Prince Edward Island, Ontario, Alberta, Nova Scotia and the Northwest Territories also signed federal-provincial accords on immigration and settlement. While Quebec maintains unique powers in immigrant selection, agreements in other provinces institutionalized devolution in settlement and set the stage for the development of Provincial Nominee Programs (Tolley 2011, 28). Provided with funding transfers under federal-provincial agreements, provincial governments across Canada also contract third sector organizations to provide frontline settlement services. Despite regional variations such as greater emphasis on French language learning in Quebec, Papillion finds these services are "generally...similar as under the federal programs" $(2002,17)$.

To some extent, scholars suggest that federal-provincial agreements allowed for the expansion of settlement programs made more responsive to local needs. In Ontario, for example, COIA established $\$ 920$ million in much-needed funding, prompting "cautious optimism" in the province's third sector (Stasiulus et al. 2011, 82). In British Columbia, McGrath and McGrath find that devolution allowed for provincial autonomy, prompting greater local engagement in language training and refugee-specific programming by increasing the "flexibility and innovation" of settlement services $(2013,13)$. At the same time, some remain critical that devolution via federal-provincial agreements did not significantly shift policymaking power in settlement. Under Prime Minister Stephen Harper, the more autonomous federalprovincial agreements in British Columbia and Manitoba were re-centralized and reverted to a comanaged system in 2012 (McGrath and McGrath 2013, 15). In Ontario, though COIA has recently been renewed, the federal government has not yet committed to additional funding. Today, many third sector professionals feel that settlement services in Ontario will "never fully recover from post-COIA clawbacks" following its expiry of in 2011 (Lowe et al. 2017, 26). Such federal-provincial agreements are also subject to provincial political shifts. The Toronto Star recently reported that an impasse regarding recent asylum-seekers between recently elected Progressive Conservative Ontario Premier Doug Ford and Prime 
Minister Justin Trudeau "sounds the death knell” for the recently signed COIA (Benzie 2018). More broadly, this recent election has also demonstrated that austerity and restructuring can be initiated through the election cycle at the provincial level. For example, one Ford's first acts as Ontario Premier was to eliminate the provincial ministry responsible for immigration and settlement, diverting their responsibilities to the newly formed conglomerate Ministry of Children, Community and Social Services.

\section{d. Canadian Municipal Governments}

In Canada, municipalities are constitutionally "creatures of the provinces" with little autonomy to make decisions independent of upper-tier government, and Rose and Preston find these arrangements "mandate little official involvement for municipalities in immigration and settlement policies" $(2016,30)$. Their role involves meeting newcomers needs and those of Canadian residents in terms of urban planning, housing, public transportation, culture and infrastructure (Papillion 2002, 19). However, partially due to demographic and settlement patterns, newcomer social inclusion has become a priority for Canadian municipalities. Canada's 2016 Census reiterated that most newcomers live in cities, with the largest immigrant communities coalescing in the metropoles of Toronto, Montreal and Vancouver (Statistics Canada 2017). Rose and Preston note that these cities "benefit when immigrants succeed but deal with the fallout when they struggle to find jobs commiserate with their qualifications, have difficulties locating affordable housing and encounter challenges settling family members" $(2016,30)$. Yet, Lim et al. find that small municipalities also face unique challenges settling newcomer residents, partially due to the higher concentration of third sector organizations in major cities $(2005,20)$. Funding limitations restrict agencies from relocating into suburban neighborhoods, contributing to what Sadiq terms "spatial mismatch" between suburbanizing newcomer settlement patterns and available settlement services (2004, 2). In 2016, Ashton et al. found "less than adequate capacities" in small, medium-sized and remote Canadian communities across the country in terms of funding, staff capability, service delivery in both official languages, mobilizing community support and strategic planning $(2016,85)$. For example, several 
studies have tied a lack of social infrastructure to increased vulnerability in the Greater Toronto Area (Lo. et al 2010; Mukhtar et al. 2015).

According to Papillion, "rapid change" began taking place at the municipal level in the early 2000s, as Canadian cities actively responded to the social exclusion of newcomer residents (2002, 19). In settlement and across social services more broadly, this phenomenon it is often linked to the retreat of Canada's welfare state. For example, following 1990s-era neoliberal restructuring in Ontario, Mwaringa notes that municipalities "now shoulder a heavier burden" and have "increasingly become the place where citizens access key services such as health, recreation, education and social services" $(2002,1)$. Stasiulus et al. similarly tie the "erosion of Keynesian social welfare arrangements experienced at all levels of the Canadian state," to "intensified involvement in settlement processes of both municipal governments and local social forces" $(2011,81)$. In Canadian cities and suburbs, they note "formidable challenges in providing appropriate, accessible, equitable and comprehensive forms of settlement assistance to a large and diverse infusion of newcomers" (Stasiulus et al. 2011, 79). Though municipalities are uniquely positioned to understand the needs of resident newcomer communities, some suggest that under neoliberal policy settlement and social inclusion have become their "unfunded mandate" (Stasiulus et al 2011; Good 2007). As Canada's cities absorb greater newcomer populations, they are gaining recognition as stakeholders in immigration and settlement. In Ontario, for example, the tripartite 2005 Canada-OntarioToronto Memorandum of Understanding (MOU) is the first Canadian legislation to include the municipal level in a multi-governmental settlement agreement (Stasiulus et al. 2011; Biles et al. 2011). However, many remain critical of the capacity for such developments to substantially affect Canadian settlement policymaking (Stasiulus et al. 2011, Rose and Preston 2016). Ultimately, in Canada's suburbs and metropoles alike, Mukhtar et al. observe that "as immigration rapidly changes population levels, municipalities... are left to manage and fund the provision of social, public and transit infrastructure to support additional people while being kept on the periphery of settlement decisions" $(2015,405)$. 


\section{e. The Third Sector in Canada}

Sadiq broadly divides Canada's third sector settlement organizations into three categories: "mainstream", "multi-service" and "ethno-specific" $(2004,12)$. Mainstream organizations include public service foundations, multicultural non-profits, large social service organizations and religious or faithbased groups. These entities work both with newcomers and Canadian residents to incorporate settlement services into broader social justice mandates of multiculturalism and social inclusion. However, they are often unable to provide programming responsive to the many languages and cultural traditions of their diverse clientele (Sadiq 2004, 12). Multicultural or multi-service agencies work specifically with immigrants and refugees, providing services to diverse range of ethnic and cultural communities from one central hub. Though these large agencies are more likely to have the capacity to provide comprehensive services, Sadiq notes that their work with multiple newcomer groups leads to the risk of universalizing client needs $(2004,12)$. Ethno-specific agencies, often located in the residential neighborhoods of client communities, target services to a particular ethnic group and are most likely to offer linguistic and cultural competency. Sadiq finds these organizations better able to "ground their service in client need" via community outreach and leadership, employment opportunities and the utilization of ethnic media (Sadiq 2004, 15). Similarly, Biles et al. view them as a "cross-cultural bridge" between newcomers and Canadian-born citizens $(2011,231)$, and Shan refers to these institutions as "bottom up social forces" $(2015,24)$. However, ethno-specific agencies are often "under-funded, staffed by non-professional volunteers and unable to provide specialized services" without adequate resources (Sadiq 2004, 12). Finally, third sector organizations of all sizes join together under umbrella organizations, which collaborate to serve collective interests of the sector. For example, the Ontario Council of Agencies Serving Immigrants (OCASI) coordinates over 225 ISAs province-wide (Biles et al. 2011, 230; OCASI). These coalitions facilitate pooling of scarce resources and promote the sharing of best practices (Tilson 2010) and provide space for effective communication with upper-tier government policymakers (Evans and Shields 2014). However, not all immigrant-serving organizations are represented in coalitions (Stasiulus et al. 2011, 111), and even within such collectives decision-making processes are not always 
perceived as unified (Evans and Shields 2014). Though Canada's third sector in settlement hosts a dizzying array of institutions, some find that its heterogenous nature actually strengthens its capacity to foster social inclusion. For Shields et al., under the right operating conditions, "the plurality of organizations and service forms they come in" allows for Canada's diverse newcomer population to seek services that are most suited to their specific needs $(2014,23)$.

As the mainstay frontline service provider for newcomers in Canada, the third sector has developed responsive service provision through close connectedness with client communities. Stasiulus et al. note that these local actors "are more attuned than upper-level governments to the complexity of local conditions that assist or impede the economic, social and political incorporation of immigrants" (2011, 132). Broadly, mainstream, multi-service and ethno-specific organizations provide counseling, housing help and advocacy, language training, health services, employment help (general and specialized), programs for women (including domestic violence, workplace training, and other programs addressing isolation), programs for seniors and youth, reception houses, information/orientation sessions, referrals and settlement workers in schools (Stasiulus et al. 2011, 106). These services correspond to the diverse needs of different groups of newcomers. For example, Nakhaie notes that refugees have more needs in "Canadian life, language and other skills training" $(2018,155)$, and others emphasize the importance of psychosocial counselling and appropriate health services in refugee communities (Navaratna 2014; Shields et al. 2014). Family class immigrants are more likely to need language and job skill training, while economic immigrants arrive with higher human capital but need help accessing "professional networks" (Nakhaie 2018, 155). Literature also notes the distinct service needs among newcomer women (Zhu 2016), youth (Kilbride \& Anisef 2001), Francophone newcomers (Bisson et al. 2011), seniors and LGBTQ+ community members resettling in Canada (Cabral 2000).

Beyond direct service provision, many suggest that Canada's third sector in settlement also extends into the political sphere. Trudeau and Veronis, for example, view settlement agencies as "active 
participants in the process of state restructuring" through the performance or resistance of/to state policies $(2009,1118)$. For Shan, agencies also "enter the field as policy actors" by articulating the needs of client communities $(2015,22)$. Evans and Shields similarly examine "non-profit voice" as the third sector sharing community-based knowledge among upper-tier government policymakers and client communities (2014, 125). Despite continued centralization of settlement policymaking, studies note that third sector organizations in Canada are actively engaged as advocates for client communities (Valenzuela et al. 2018; Shields et al. 2014). On a societal level, third sector organizations also influence attitudes towards newcomers among Canadian-born populations through equity, diversity and anti-racism campaigns. As Richmond and Omidvar note, the third sector is equally essential as service providers and as advocates for newcomers, "maintaining the public support" which makes settlement and social inclusion in Canada a two-way process $(2003,7)$. 


\section{Chapter 3: Themes in Canada's Third Sector in Settlement}

According to Richmond and Shields, the intended effect of New Public Management governance in Canada's third sector is to "bring the rigours of a business or private-sector approach to perceived service inefficiencies among non-profit organizations" $(2005,518)$. From the neoliberal perspective, organizations competitive in this policy environment and those whom the public chooses to support "through their charitable giving and voluntary activities" are the most cost-effective and are therefore most deserving of government investment (Richmond and Shields 2005, 518). However, as Richmond and Shields note, NPM is "not working...for the settlement sector nor the newcomers they serve, nor is it working for the Canadian non-profit sector as a whole" $(2005,518)$. By lessening its capacity to serve immigrants and refugees in Canada, available literature suggests that neoliberal austerity and restructuring processes have weakened third sector settlement organizations and contributed to social exclusion among their immigrant and refugee clientele.

\section{a. Program loss and mission drift}

For Cabral, the third sector facilitates social inclusion throughout the long process of settlement by providing comprehensive care that addresses the immigrant experience "in its totality" $(2000,13)$. Unfortunately, in the neoliberal policy environment, funding limitations disengage the third sector from client communities as agencies tasked to "do more with less" are forced to cut key programming (Shields 2004, 6). These program cuts feed into a cycle in which newcomers encountering greater barriers in settlement are less and less able to rely on comprehensive, accessible and available third sector services. As Shields notes, settlement services "have been cut back... just as the demand for them has climbed" (2004). Furthermore, program losses disproportionately affect newcomer clients with the greatest need for settlement aid. Baines et al. find that cutbacks often include "small and financially modest supports" including public transport, childcare and the ability to offer "a bit of light food" to clients $(2014,88)$. Mukhtar et al. also find cuts particularly prevalent in childcare, youth outreach and evening courses or service hours (Mukhtar et al. 2015, 401). For groups already at a higher risk of social exclusion, including 
those without status, youth, women, elderly and low-income newcomers, the loss of comprehensive service models particularly problematizes access to settlement services. Even where third sector agencies maintain program inventories, Richmond and Shields note that "increasingly fees for services are being introduced" for key support services $(2004,8)$. As the third sector loses programming and becomes disconnected from its client communities, newcomers in Canada are further removed from settlement aid and find themselves at greater risk of social exclusion.

Contract funding not only shapes service availability, but also "transforms" the development and implementation of settlement programming (Richmond and Shields 2004, 8). On one hand, Neudorf finds that recently, longer-term contracts between third sector agencies and the federal government have "reduced the time spent haggling over funding agreements" and have generally been well-received (2016, 97). Nonetheless, as Evans et al. note, more broadly "the contract funding scheme tends to impose government funding priorities on non-profit organizations dependent on state revenues," while agencies "juggle" their mandate to meet upper-tier government funding and contract agendas $(2005,81)$. Richmond and Shields describe this process as "mission drift," whereby the founding ethos of an organization becomes compromised to attain critical government funding $(2005,518)$. Shields et al. note that "economic integration and short-term measurable results" are prioritized by government funders over comprehensive programming $(2014,20)$. For example, Trudeau and Veronis find that Toronto agencies, well-aware of funder priorities, "focus their services on employment" by offering programs in computer skills, job applications, interview techniques and networking $(2009,1125)$, though Stasiulus et al. note that such programs avoid "the more complex and difficult discussions of systemic inequalities in the workforce and the racialized dimensions of these inequalities" $(2011,118)$. While employment programming is imminently useful for newcomers in Canada, it is of concern that such services are offered "as a matter of competition and organizational survival" and without addressing the root causes of barriers to the Canadian labour market (Trudeau and Veronis 2009, 1125). For Stasiulus et al., this is 
"illustrative of the limitations of neoliberal assumptions" in newcomer settlement and underscores the importance of comprehensive funding for an autonomous third sector $(2011,118)$.

\section{b. Particular challenge to ethno-specific organizations}

Many have noted that small, ethno-specific organizations are particularly important actors in Canadian settlement due to their cultural and linguistic compatibility with particular newcomer communities. (Sadiq 2004; Biles et al. 2011; Shan 2015). Shields et al. find that clients reliant on ethnospecific organizations are more likely to be "particularly vulnerable immigrant populations who can be hard to reach and service through more standard service bodies" $(2014,23)$. Though neoliberal policy has weakened Canada's settlement sector overall, available literature demonstrates particular challenges for these critical agencies that do not have the same resources as larger, multi-service agencies in terms of administration, management and professional development (Sadiq 2004; Shields et. al 2015; Acheson and Laforet 2013). On the other hand, Sadiq notes that multi-service agencies "possess an enhanced capacity to complete grant proposals and win government contracts" $(2004,6)$. Neudorf adds that multi-service agencies are able to rely on administrative skills and networks won over "many years of partnership" with Canada's federal government $(2016,99)$, and for these same reasons Shields et al. conclude that "larger, professionally-oriented" agencies have become the government's preferred partner in settlement service provision $(2014,22)$. Multi-service organizations are able to utilize this competitive advantage to ensure institutional stability despite the "chaotic funding environment" in Canada (Richmond and Shields 2004, 9). For example, examining 1990s cutbacks in Ontario's settlement sector, Sadiq estimates that funding losses in ethno-specific agencies were nearly twice that of losses in multi-service agencies, noting that many had to close as a result $(2004,13)$. According to Mukhtar et al., these agencies also enjoy "modest autonomy" and are better able to plan for the future as they can rely on consist ant flow of government funding $(2015,392)$. 
Unable to compete with other organizations for funding contracts, ethno-specific organizations in Canada are forced to make difficult choices regarding service provision and organizational identity. Acheson and Laforet find that they "willingly adapt to the new governance requirements" by scaling operations to "cater to a wide range of constituencies" but compromising services for certain client communities $(2013,611)$. They profile one organization that made the "conscious decision to reconfigure as a mainstream service provider" and, in doing so, worsened relationships with the "highly marginalized new immigrant group" they had originally served (Acheson and Laforet 2013, 610). As one key informant noted, in a neoliberal policy context "you have to be serving everybody... an ethnic organization... is not going to go anywhere" (Acheson and Laforet 2013, 610). Of course, mainstream and multi-service organizations are also critically important actors in Canada's settlement sector. However, in losing its heterogeneity and the particular services provided by ethno-specific organizations, the sector is made less responsive to the needs of immigrants and refugees most vulnerable to social exclusion. Citing AratKoc's (1999) concept of neoliberal policy redefining newcomers as "deserving” or "undeserving” based on their economic contribution to Canada, Shah thus finds third sector organizations also fall into this binary based on "the various services and programs they offer, and the clients they serve" $(2015,42)$.

\section{c. Loss of non-profit advocacy role}

During the Keynesian era, Evans and Shields note that governments "guided by a reform liberal/social democratic framework" provided funding not only for service provision but also to amplify the voice of minority groups in society $(2000,5)$. Acheson and Laforet similarly note that the development of community groups was "a key feature of the post-war system of representation in Canada," providing space in which "citizens could attain and practice the skills of citizenship" (2013, 603). Today, many invoke the concept of a "community voice" in describing the way that third sector organizations articulate the needs and interests of their newcomer clients (Valenzuela et al. 2018, Lowe et al. 2017). Alongside direct service provision, Evans and Shields note that these organizations are also responsible "as drivers of advocacy for public education and policy change, as mediators, in connecting 
stakeholders and as builders of citizenship, promoting participation and membership in a community" $(2000,6)$. As immigrants and refugees in Canada are subject to social exclusion in various forms, and “especially since some $70 \%$ of them are identifiable minorities," they suggest this advocacy role is particularly important in critiquing upper-tier government policies that exacerbate social exclusion in Canada $(2014,119)$. Yet, third sector advocacy exists in a variety of forms. Evans and Shields also note the equal importance of "small advocacy" as "behind the scenes, day-to-day interface and consultation" between the third sector and government representatives $(2014,119)$, and Valenzuela et al. address "soft advocacy" activism "directed at society, rather than at government policies" $(2018,78)$. Where equity, anti-racism and multicultural outreach helps the Canadian-born population better understand the challenges of settlement, they are enabled to advocate for their newcomer neighbors. For this reason, Richmond and Shields note that third sector advocacy is fundamental in "making integration a two-way street," activating social inclusion not through government policy but also in Canadian society $(2005,39)$.

In contrast to earlier eras in settlement governance, literature suggests that the third sector role as community advocate has been threatened by Canada's contemporary neoliberal policy environment. Government funding contracts rarely recognize advocacy initiatives, which are seen as “'special interest' activities which government funds should not be associated with" (Baines et al. 2014, 79). This phenomenon is widely referred to as "advocacy chill," whereby third sector organizations deeply dependent on government funding become, as Evans and Shields note, "hesitant to bite the hand that funds them" $(2014,125)$. Valenzuela et al., too, find that diminishing advocacy activities in the third sector reflects "NGO hesitancy to put themselves in a compromising position with funders" $(2018,77)$. To maintain institutional stability, Acheson and Laforet find that "organizations must focus on service delivery at the expense of promoting political change" $(2013,607)$. For example, they profile Ottawa organizations that "had seen their funding rescinded because they engaged in advocacy or criticized government" $(2013,606)$. Evans and Shields similarly find that "the cold hand of advocacy chill remains very evident..." among Ontario settlement agencies in consultation with provincial policymakers (2014, 
125). For Valenzuela et al., "de-politicization" as such has two major long-term consequences. Not only is "the non-profit sector losing ground... to influence governments regarding immigration policies and programs" but 'advocacy chill' can also “undermine an organization's legitimacy with clients" as representative of their collective interests (Valenzuela et al. 2018, 77). Ironically, advocacy chill ultimately works to government disadvantage even within a neoliberal framework. As Evans and Shields note, by distancing client communities from settlement organizations and "chilling" third sector capacity to meaningfully influence policy, upper-tier governments disregard "alternative perspectives" that could prove valuable in establishing more efficient, effective social inclusion initiatives $(2000,14)$.

\section{d. Precarity in the settlement sector}

Literature widely notes that Canada's settlement sector is made "precarious" (Baines et al. 2014; Richmond and Omidvar 2003; Valenzuela et al. 2018) and "expendable" (Acheson and Laforet 2013, 598) as a result of neoliberal government policy. Baines et al. define precarity as "lack of security and/or predictability... as it relates to unemployment," noting that it induces self-reinforcing cycles of "vulnerability, instability, marginality and temporariness" within third sector agencies and their client communities $(2014,75)$. These cycles initiate in the sector itself, as underfunding and market-based reforms worsen working conditions. While many see employment in the third sector as a "labour of love," Baines et al. note that "organizational missions and values are... not sufficient to provide a sustainable road to employee retention" in the sector $(2014,86)$. Many note the prevalence of poor pay, overwork and burnout at the frontlines of non-profit settlement services, as already stressful jobs are made increasingly precarious by underfunding, lowered benefits, worsening wages and the erosion of job security (Lowe et al. 2017; Richmond and Shields 2004, Baines et al. 2014). For example, Mukhtar et al. find that in Ontario's Peel Region, settlement agency staff reported "increasing mental and emotional stress...due in part to the nature of the job (e.g. working with clients who face challenges in integrating) and also to the pressure of being overworked in an underfunded organization" $(2015,401)$. Many also note the particular precarity of settlement sector staff who are themselves newcomers (Baines et al. 2014; Jayaraman and 
Bauder 2013). Jayaraman and Bauder find it unfortunate that a sector so "keenly aware" of the challenges faced by newcomers in the labour market can only provide key newcomer employees with "low pay, long hours, unfavourable working conditions and limited career advancement opportunities" $(2014,179)$. Particular concern is noted in terms of the labour market segmentation of racialized newcomer women, who often dominate the staff composition of third sector agencies (Jayaraman and Bauder 2014; Lowe et al. 2017). Yet, for Shan, labour market segmentation is designed not by the sector itself but through neoliberal "social and economic hierarchies" that have gutted its human infrastructure $(2015,26)$. For her, continued capacity of the third sector to provide settlement services and empower clients becomes increasingly "critical" in this context (Shan 2015, 26).

Where the third sector is inadequately staffed, it becomes precarious both at an individual and organizational level. Baines et al. note that "permanent temporariness" of short-term contract work breeds vulnerability "into the DNA of the sector," as few staff remain to embed "institutional memory" and the wealth of experience into new projects $(2014,84)$. Even where projects are operationalized, "staff are unlikely to be around to actualize these plans or feel they have the overview to set goals for a very unstable future" (Baines et al. 2014, 84). In the context of increased competition, multi-partner projects, fewer volunteers, increasing demand for services and computerization, Evans and Shields find the loss of qualified staff has "strained the capacity of many community organizations to their very limits" in meeting demanding accountability and reporting mechanisms instituted under NPM $(2000,11)$. For example, Baines et al. find it "not uncommon" for such activities to absorb twenty percent of the workday for service deliverers $(2014,85)$. According to Richmond and Shields, the "continual multiplication" of administrative activities stresses agencies to the point that their performance is significantly eroded (2005, 519), and elsewhere Shields et al. note that these processes sap "innovation and ability" from Canada's settlement sector $(2014,20)$. Given workload increases and continued underfunding, Richmond and Shields estimate that "retention of quality staff will become increasingly significant," further reducing the ability of Canada's third sector to provide government funders with measurable outcomes desired under 
NPM governance $(2004,12)$. Ultimately, this “perverse kind of interaction” (Richmond and Shields 2005, 520) multiplies precarity among newcomer clients less likely to receive appropriate supports from third sector organizations upon which they increasingly depend.

To foster accountability in Canada's third sector and improve settlement outcomes, the government might focus on increasing its capacity to face such challenging operating conditions. Yet, little government funding is available for settlement sector development. Neudorf notes that the federal Settlement Program allocates $15 \%$ of the national budget for program support and administration, and only $10 \%$ for sector development $(2016,102)$. In 2016 , for example, of approximately $\$ 600$ million in federal funding for settlement services outside Quebec, this allows for a combined total of $\$ 150$ million for program supports and administration, professional development activities, conferences, umbrella organizations, consultations and intra-sectoral coordination (Neudorf 2016, 102). In a "struggle to survive" under these conditions, key informants note that "organizations will try to take on too many programs" to pursue larger funding contracts, creating a vicious circle of overwork and underfunding (Neudorf 2016, 103). In contrast to neoliberal paradigms, federal disinvestment has led Canada's settlement sector to become less cost-efficient. Third sector informants suggest that larger allocations for capacity building "would improve the benefits of the programs... already delivered," as organizations could attain economies of scale in properly administering programming and professionalizing long-term staff (Neudorf 2016, 103). Instead, as Neudorf notes, it seems that Canada's government continues to rely on inter-agency collaboration "to fill the gaps" where organizational capacity is lacking $(2016,103)$.

\section{e. Third sector collaboration and coalitions}

As the Canadian government implements NPM in the settlement sector, it promotes partnerships between agencies as a measure to reduce funding and the duplication of settlement services (Mukhtar et al. 2015). Tilson cites CIC's 2011-2012 Guide for Applications for Settlement Program Funding, noting that "partnerships between service-provider organizations are encouraged, as are joint proposals" (2010, 
12). Neudorf also notes federal preference in funding collaborative initiatives as such projects ultimately "mitigate risk for the funder" $(2016,101)$. There is also evidence that third sector agencies actively pursue partnership initiatives. In a 2009 study among North America settlement service organizations, Trudeau and Veronis find inter-agency collaboration to be "a coping strategy in response to new funding regimes..." and "an intentional decision...to respond to specialization pressures, such as providing needed services that are ignored by the state and the market" $(2009,1127)$. Sadiq cites Bartlett and McKitrick (1999) in identifying six distinct forms of collaboration including:

"1) shared activities- such as cultural events, overseas aid, and community information events, 2) partnerships - where organizations share meeting space or where meeting space is supplied by other organizations (such as community centers), 4) coalitions - mutual support between different kinds of human rights and community groups- 5) information networks - via information sharing meetings or coordination of a shared resource center and 6) sponsorship - where small agencies receive funding and other resources from large organizations and umbrella groups" $(2004,17)$.

Through such projects, agencies pool resources to increase capacity, attract funding and soften the burden of government austerity. In particular, Acheson and Laforet note that partnerships with larger, multi-service agencies can become "a buffer, funneling resources to mono-ethnic organizations" with less resources in terms of space, grant-writing and administrative expertise $(2013,607)$. These partnerships can be equally beneficial for the larger partners, who gain broader reach in cultural and linguistic compatibility. Where this is made possible, Sadiq notes that "services to the broader newcomer community are enhanced," and better able to meet diverse client needs $(2004,18)$.

Unfortunately, though NPM governance in Canada's third sector incentivizes third sector partnership, literature suggests that it also challenges these very alliances. These issues are especially prevalent in partnerships between ethno-specific and better-funded multi-service agencies. For the former, Sadiq find that concerns in entering into such a partnership surround competition and co-optation fostered by unequal power dynamics and financial dependency (2004). Similarly Mukhtar et al. suggest that where organizations with similar mandates "fight for clients," it is likely that larger agencies will win government contracts $(2016,400)$. However, even where a partnership is successfully formed, other 
issues emerge. One respondent from an ethno-specific agency likened these unions to "the Wal-Mart of community services," as larger partners "kind of take-over" and, in doing so, erode particular cultural and linguistic features of a partner agency $(2016,400)$. Sadiq coins the term "two-tier dependency" to describe this state in which, in the first tier, large ISAs remain dependent on the Canadian government for funding, and in the second, ethno-specific agencies are equally dependent on multi-service partners (2004, 18). He finds that, in particular, ethno-specific agencies are "subject to the financial and everyday social control of their so-called collaborative partners," and are sometimes made less accountable to newcomer clients as a result $(2004,27)$. Sadiq further demonstrates that "two tier dependency" also causes "spatial mismatch," as smaller organizations may co-locate with larger collaborative partners but, in doing so, physically distance themselves from the ethnic and cultural communities that they once served $(2004,19)$.

Umbrella coalitions are another form of partnership that has gained prevalence in Canada's third sector over the last few decades. These forums, often described as "a collective voice" for the third sector, allow agencies to coordinate service provision and cooperate in the sharing of best practices (Acheson and Laforet 2013, 604; Evans and Shields 2014, 123). Scholars examine the growth of umbrella organizations in individual cities, like the Ottawa's Local Agencies Serving Immigrants (Acheson and Laforet 2013), as well as at the provincial level across Canada (Evans and Shields 2014; Germain and Trinh 2011; Stasiulus et al. 2011). Open only to agencies with the primary mission of serving newcomers, Evans and Shields note that these coalitions have been "generally...effective" in amplifying third sector voice among upper-tier government policymakers in Canada $(2014,123)$. Lowe et al., too, find that third sector respondents who perceive "advocacy chill" within individual agencies felt their views better heard through collective advocacy $(2017,36)$. For these reasons, Neudorf characterizes umbrella organizations as a "keystone that balances elite brokerage with grassroots input" in Canadian settlement $(2016,101)$. Interestingly, upper-tier governments are also invested in the formation of such groups. As Stasiulus et al. note, policymakers find it is simpler "to consult with one coordinated voice... rather than dealing with the cacophony of a thousand disgruntled agency voices" $(2011,111)$. 
Unfortunately, literature suggests that discord in the sector, exacerbated by the competitiveness of contract based funding, lessens the collaborative capacity of umbrella organizations (Lowe et al. 2017; Stasiulus et al. 2011). For example, in Evans and Shields' study among agencies in Ontario settlement coalitions, one respondent noted the contradiction that "we are all fighting for the same money, so you are trying to share a common voice...but then we are trying to steal your funding at the same time" (2014, 124). Even where collaboration is possible, Acheson and Laforet find that agencies identify as complementary service providers rather than under broader shared ideologies of "inclusion, participation, social protection and rights protection" $(2013,612)$. Ultimately, many organizations found it difficult to engage in "longer-term solidarities and collective projects" (Acheson and Laforet 2013, 612). More broadly, the capacity of umbrella coalitions to affect meaningful policy change is unclear. Lowe et al. are troubled by the ways in which these forums are "increasingly monitored and controlled" by the Canadian government, who have welcomed consultation with umbrella coalitions but are in no way compelled to incorporate their expertise into decision-making processes $(2017,36)$.

\section{f. Multi-sectoral partnerships in settlement}

Social inclusion is best realized in Canada where shared objectives in settlement, rather than strict funding contracts, align the government and third sector in equitable partnerships. For Meinhardt et al., this partnership ideally includes "shared vision and values; clear goals; good personal relationships; frequent interaction; expectation of mutual benefit; shared power and risk; and mutual trust" $(2015,5)$. To some extent, literature notes these characteristics on several levels of Canadian settlement. For Shan, best practices mandate newcomer involvement in the design of settlement services and in policymaking through a "participatory mode of governance" $(2015,26)$. Germain and Trinh note this type of collaboration in Quebec, where community roundtables have been held by municipalities, organizations and community representatives since the late 1990s in liaison with the provincial government (2011). Local Immigration Partnerships (LIPs), emerging from multi-governmental consultations in Ontario, have worked similarly on a nation-wide basis. According to Pero, these forums unite diverse stakeholders 
including third sector organizations, umbrella organizations, research and academic bodies, the private sector, all three levels of government and newcomers themselves to create "a community-built strategic plan and a collaborative local council" which researches, reports, establishes and implements settlement strategies responsive to local needs $(2017,75)$. By 2017, LIPs had spread from Toronto to 77 cities across Alberta, Newfoundland, Nova Scotia, British Columbia, Saskatchewan and Manitoba, and the Northwest Territories (Pero 2017, 75). Many are optimistic about LIPs, in that they increase recognition of local expertise in settlement (Biles et al. 2011), foster knowledge transfer from newcomer communities to the upper-tier government policymakers (Tilson 2010; Andrew and Bradford 2010), and results in more responsive, localized settlement policies (Siemiatycki and Triadafilopoulos 2010). Stasiulus et al. find that, as partnerships based on "cross-sectoral collaboration and input," LIPs embody a shift from "specific, administrative boundaries and the clear exercise of power... by government" to "governance" in Canadian settlement policy through "cross-sectoral collaboration and input" $(2011,113)$.

Though many note increasing horizontality in Canadian third sector-state partnerships, literature suggests continued challenges in this realm. For Meinhardt et al., partnerships in settlement rely upon to the extent to which "the state recognizes the autonomy of the voluntary sector without imposing its political will" $(2016,284)$. For the most part, it appears the partnership between the Canadian government and settlement sector remains asymmetrical in this sense, as many experts find that power ultimately rests with government funders (Canadian Council for Refugees 2011; Kilbride and Anisef 2001; McGrath and McGrath 2013; Papillion 2002). Meinhardt et al. note that these imbalances extend beyond "control of the purse strings, as the Canadian federal government makes unilateral decisions based on an "an economic and accountability perspective" in line with neoliberal policy frameworks rather than long-term social inclusion $(2016,292)$. They find third sector respondents critical of the "dictatorial nature" of government partnerships, to the point of questioning whether such relationships "can be called partnerships at all" (Meinhardt 2016, 291). Papillion, too, argues that the "quasi-institutionalization" of Canada's third sector as settlement service providers has not been accompanied by their recognition in the policy-making 
sphere, which remains "largely a top-bottom process" $(2002,20)$. Examining relevant literature, it is clear that "centralized decentralization" is not a new trend, but has persisted in Canada for decades (Evans et al. 2005, 88). In 2000, Evans and Shields noted that settlement policy was set through "essentially hierarchical and rule driven structures," (17) and by 2014, they found that little had changed in that the third sector still had "very limited possibilities to influence policy" (125). Other recent works echo their findings. Neudorf concludes that "vestiges of hierarchical governance and coordination still exist as IRCC's Ottawa headquarters still exercises considerable directions and control" within the Canadian settlement system $(2016,104)$. For Stasiulus et al, recent innovations in settlement "do not signal a major shift in decentralization or power-sharing in immigration policymaking" and that today's third sector-state partnerships are, at best, "a mixture of horizontal and hierarchical relations" $(2011,131)$.

That neoliberal austerity problematizes multi-sectoral governance in settlement is made clear in closely examining Local Immigration Partnerships. According to IRCC, only the "coordinator role" of LIPs is federally funded, and project implementation requires that these councils seek outside funding (2016). IRCC found that nearly half of LIPs were unable to report additional outside funding, and that only $30 \%$ had completed project implementation by 2016 (IRCC 2016, 8). They concluded that “projectspecific funding or the support needed to secure funds remains a challenge" which "jeopardizes the implementation of long-term work" (IRCC 2016, 15). In an independent review, Bradford and Andrew observe that LIPs have few resources to move into implementation phases of community projects (2010, 14), and Stasiulus et al. questioned their "durability" in the context of funding limitations (2011, 114). For Evans and Shields, poor recognition and support of local settlement stakeholders within Canada's uppertier governments neutralizes "the real potential for a framework of collaborative partnership to deepen democracy and citizen representation to the state" $(2000,16)$. Stasiulus et al., too, find that "if the shift to multi-scalar, multi-sectoral governance in immigrant matters... is to benefit more than a handful of newcomers...the federal government will need to show greater responsiveness and democratic openness to more localized voices in settlement policies" $(2011,133)$. 


\section{Chapter 4: Settlement and Social Inclusion in Germany}

Germany, like Canada, is a federalist state with multiple tiers of governance including the federal, Länder or state and municipal governments. At the supranational level, the European Union (EU) also influences immigration and settlement in Germany. In the second half of this paper, these actors will be briefly outlined in relation to Germany's third sector, though they must first be contextualized within the broader economic and political context of German settlement governance. As Valenzuela et al. note, developments in settlement "have taken place and in part been shaped by a world shaped by neoliberal ideas" $(2017,67)$, which are evident in Germany as well as Canada. Examining "neoliberal times" (Valenzuela et al. 2017, 65) in Germany through a third sector lens allows for better understanding of settlement and social inclusion both on a national and cross-national scale.

\section{a. Settlement Governance in Germany}

Bauder notes that following World War II, "and in light of the catastrophe that followed a misguided interpretation of German nationhood during the Third Reich," ethnocultural nationalism was replaced by Wirtshaftswunder, or the "miracle of economic recovery" $(2008,59)$. In this context, "an advanced welfare state" inspired by the Swedish welfare model was implemented in Germany (Bauder 2008, 59). To fuel economic growth, Germany also initiated a series of programs to admit guest workers from Italy (1955), Spain (1960), Greece (1960), Turkey (1961), and Yugoslavia (1968), under the assumption that they would eventually return to their home countries (Sherr 2013). The 1973 oil crisis, global economic competition and rising unemployment rates prompted an anwerbestopp or Recruitment Ban for foreign labour as the German government began promoting voluntary repatriation. Yet, Bokert and Bosswick note that such policies "unintentionally led many foreigners to stay in the country, as the option for re-entry was explicitly rejected," $(2007,5)$. Green estimates that nearly four million immigrants, the majority of whom were Muslim Turks, remained to make West Germany "home for good" $(2005,190)$. 
During the 1980s, many note a sharp nationalist shift in German immigration and settlement policy. Green, for example, characterizes this era in terms of "an aggressive and resurgent nationalism" $(2005,192)$, and Bauder notes that immigration was seen not only as an economic drain but "a challenge to civil order and social cohesion" $(2008,59)$. For Bokert and Bosswick, these attitudes also linked to increasing xenophobic attacks against newcomers in West Germany (2011). As the German economy was further burdened by reunification costs in 1990, market liberalization and retrenchment of the welfare state became popular policy among the Conservatives in power (Friedrichs and Klöckner 2009, 92). Little formal settlement programming existed at this time, both as a result of neoliberal cutbacks and limited recognition of non-Germans as permanent fixtures of German society. Instead, Schönwälder and Triadafilopoulous note that fear of social divisions and "parallel societies" remained at forefront of debates on immigration in the 1990s and early 2000s. This distrust, "now more or less openly of Muslims," was tied to debates on religious pluralism in Germany (Schönwälder and Triadafilopoulos 2016, 371), though Amir-Mozami notes a multicultural "counter-discourse" among a number of academics and politicians $(2005,16)$. This debate was well-captured in the 1990 renewal of the Foreigner's Law, which provided new pathways to naturalization but, according to Bokert and Bosswick, remained "restrictive" in nature $(2007,6)$. Yet, as the German economy grew stronger, Bauder finds that an "economic utility perspective" increasingly framed these issues $(2008,55)$. The 1991 Anwerbestoppausnahmeverordnung or Recruitment Exception Regulation exempted flexible, temporary workers in high-demand industries from the recruitment ban (Bokert and Bosswick 2007). In 2000, the Green Card program also initiated recruitment of skilled IT experts in Germany's expanding information and communications technologies industry. For Bokert and Bosswick, this was a "sharp turn... towards the notion of immigration as an important resource in global competition" $(2011,110)$.

Maletzky finds that the new millennium brought a "massive change in the public discourse... from the image of the lazy immigrant... towards that of useful, productive immigrants who could be a fundamental part of economic growth" $(2017,10)$. For Bauder, these neoliberal attitudes influenced 
Germany's 2005 Immigration and Residence Acts which, following a period of intense parliamentary discussion, expanded temporary foreign worker programs and residency for skilled and self-employed immigrants (2008). However, due to "fears that immigrants would either steal the jobs of Germans or become a burden to the welfare system," the new legislation did not significantly shift restrictive immigration and settlement policies in Germany (Bauder 2008, 72). Overall, as Bauder notes, this legislation was "consistent with the wider neoliberal project" sweeping throughout Germany, exemplified more broadly in the 2002-2005 Hartz welfare reforms (2008, 59). According to Dostal, the Hartz policies cut unemployment entitlements, contributing to the "rapid expansion of low-wage and non-standard forms of employment in a deregulated labour market, in which the share of the share of the working poor has grown rapidly" $(2017,590)$.

Today, immigration and settlement remains a divisive social issue in Germany. Several scholars note the popularity of Deutchland schaff sich ab or Germany Abolishes Itself, a potently anti-immigrant publication authored by prominent banker Thilo Sarrazin, as well as Chancellor Angela Merkel's oftquoted 2010 statement that "multiculturalism has utterly failed" (Campbell 2012; Blither and Ziebart 2016). Yet, as Campbell notes, "others... argue that Germany needs immigrant workers to maintain its position as Europe's strongest economy," particularly given Germany's aging population and declining birth rates $(2012,451)$. For Schönwälder and Triadafilopoulous, "Germany does not quite fit into narratives that centre on the arrival and departure of multiculturalism...," and they instead describe its outlook as "new differentialism" that simultaneously calls for a "culture of welcome" and demands rapid cultural and labour market integration of newcomers $(2016,367)$. For them, this contradiction helps to explain the "surprising openness" Germany to recent migrants and asylum-seekers at the same time as the increasing political prominence of right-wing, anti-immigration Alternative Fur Deutschland (AfD) party (2016, 367). Green finds that German settlement discourse, underpinned by the ethos of "integration," is 
concerned with "the extent to which non-nationals should be expected to assimilate (i.e take on the majority culture), and how the norms to be accepted by all immigrants or non-nationals...should be defined" $(2005,199)$. Schönwälder and Triadafilopoulos, too, find the resettlement process in Germany "individualist" at its core, as “everyone is responsible for his or her fate, including their 'integration' and state institutions play only a minor role to provide support and guidance for such efforts" $(2016,377)$. This, too, reflects neoliberal policy ascendant in Germany, Canada and throughout the Global North since the 1980s. Much like in Canada, the German third sector has become a pillar of settlement support for immigrants and refugees in absence of federal programs. Having situated German settlement in its historical context and in modern neoliberal policy, addressing the various governments involved will more clearly outline the development of this key third sector role.

\section{b. The European Union}

In 1957, West Germany was one of six founding members of the European Economic Community, an early iteration of the European Union (EU). Member states formed agreements in migration as early as 1975, through a counterterrorism arrangement called the Trevi group (Hubschmann 2015, 10). In 1985, the Schengen Agreement coordinated immigration and asylum policies, and in 1990 the Schengen Convention dissolved internal border control and established a common visa and border free movement across the European Union. According to Hübschmann, EU cooperation in immigration was further strengthened in the Maastricht Treaty of 1992 and the Amsterdam Treaty of 1997 (2015, 10). The Dublin Convention, implemented in 1997 and replaced by Dublin II in 2003, has become the most important pan-European agreement in erecting a safe third country structure in Europe. Developing into one of the region's strongest economies, Germany has become an increasingly important voice within in the EU. Today, Bokert and Bosswick note their greatest spheres of influence within EU policymaking forums to be "the harmonization of asylum rights, border control and readmission and burden-sharing" 
(2011, 113). German leadership in these matters was signalled by their suspension of the Dublin stipulations in 2015, attempting to lessen the burden of poorer EU countries by admitting Syrian refugees regardless of which member state they first entered. The Dublin regulation has recently been upheld in the European Court of Justice despite high numbers of asylum applications, though the European Council found that of over 745,545 asylum applications in Germany, less than 4000 or $0.5 \%$ were eventually returned to their country of first entry (Eurostat 2017).

Hübschmann finds that despite "considerable progress" in coordinating immigration and asylum procedures across EU member states, "much less has been done in the realm of migrant integration" $(2015,10)$. Such matters are difficult to standardize and implement across states with diverse histories, geographies and politics, and for the most part remain the prerogative of national governments. Yet, Hübschmann notes increasing calls for EU-wide settlement policy action plans, finding it "crucial to discuss these programs, their failures and successes" given Europe's increasing prominence as a migrant destination $(2015,12)$. Relevant literature suggests that EU policies influence settlement politics and policy in Germany to some extent. In detailing the rollout of the 2005 Immigration Act, for example, the

federal government announced that they have done "a great deal" to translate EU immigration and asylum policies into national law (Kohlmeier et al. 2006, 26). On a more localized level, Schmidke finds that EU funding empowers third sector organizations and municipalities, and thus has been "instrumental in challenging the national government in their exclusive authority over this policy level" $(2014,94)$.

\section{c. German Federal Government}

Like Canada, Germany is a federal system with multiple tiers of governance involved in newcomer settlement. Similarly, too, these powers are divided amongst the federal government and sixteen Länder states. Under Article 31 of Germany's Basic Law, federal prerogative takes precedence over that of the Länder (Deutcher Bundestag 2014), though Klages and Löffler note that the German federal government "largely concentrates on policy-making and policy advice" and allows for state 
autonomy in policy administration and implementation $(1998,46)$. Until 2005, the federal Ministry of Labour and Social Affairs organized newcomer settlement in Germany in language and employment training as well as the issuing of work permits for temporary workers and Green Card holders. However, through the 2005 Immigration Act, responsibilities in settlement were centralized in the Federal Ministry of the Interior, under the new Federal Office for Immigration and Refugees (BAMF) and in coordination with The Federal Government Commissioner for Migration, Refugees and Integration. At this time, BAMF became responsible not only for immigration and asylum proceedings but also for designing a formal program "for the social integration of re-settlers and foreign nationals residing long-term in Germany" (Kohlmeier et al. 2006, 10). It should be noted that BAMF is separate from the Federal Office of Administration, which independently coordinates the admission and resettlement of Aussiedler, or ethnic German minorities resettling from former Soviet states.

Süssmuth notes that one consequence of the federal government's long-term denial of guestworkers' permanent settlement in Germany is that settlement policy has "lacked coherence and failed to provide a long-term rationale" $(2009,1)$. These issues were addressed for the first time through Germany's National Integration Plan, released in 2006 following the Immigration Act and the convening of a high-profile, multi-sectoral Integration Summit. It centers on 700-hour integration courses, designed to provide and test "sufficient knowledge of the German language and... about everyday life in Germany, as well as concerning the legal system, culture and history of Germany and the principles of rule of law, equal rights, tolerance and religious freedom" (Kohlmeier et al.. 2006, 24). These courses, often provided by federally-funded third sector organizations, have been made mandatory for newcomers without a working knowledge of the German language. Controversially, newcomers' residence and social welfare rights depend on attendance and testing records. In 2012, BAMF assessors noted that over 700,000 newcomers had participated in integration courses described as generally "well-accepted" (BAMF 2012, 10). In 2016, in light of increased asylum applications, the Integration Law further funded these courses but also enhanced punitive measures for non-attendance, additionally restricting residence rights for 
newcomers unable to fully provide for themselves. Controversially, this law also introduced "one euro jobs" for newcomers, or unemployment work schemes paid by a government subsidy up to 2.50 euros an hour. On the BAMF website, it is stated that these policies underscore that immigrants and refugees in Germany are "required to work for their own integration" (2016).

Many are critical of Germany’s federal approach to settlement. Broadly, activist lobby group Pro Asyl has argued that these measures project unwillingness to integrate on newcomers "when the real problem lies with the government's failure to provide adequate training, support and job opportunities" (Wagstyl 2016). Others take issue with the mandatory integration courses. As Prem notes, eligibility for such programs is "strictly reserved" for newcomers holding a residence permit and refugee claimants likely to gain positive status determination including those from Syria, Iraq, Iran, Eritrea, and Somalia (2017, 119). It is provided free of charge for some groups, including ethnic German Aussiedler and those on unemployment benefits. Others pay nearly two euros per hour, amounting to 1,365 euros over 700 hours (BAMF 2018). Notably, this cost has nearly doubled in the decade since integration courses were first introduced. Even among newcomers who can afford this cost, many are ineligible for these courses, including asylum-seekers who have been rejected but cannot be deported for lack of documentation and those from "so-called secure countries of origin" like the Balkan states, Ghana and Senegal (Prem 2017, 122). Without access to integration courses, further social exclusion compounds the multiple vulnerabilities of non-status groups in Germany. Another critical view more broadly situates mandatory integration courses within a neoliberal policy framework. Among European countries, Goodman finds Germany has the most "multiple onerous barriers to citizenship" despite modest liberalization in the early 2000s $(2010,759)$. As the opportunities for naturalization are limited, she suggests that that integration courses are not solely "functional," but also represent "political-symbolic" policy that offers "welcome culture" only to those who can absorb the financial burdens of assimilation (Goodman 2010, 766). 
Recent developments in German federal politics relevant to immigration and settlement policy reflect vast divisions at the federal tier. Dostal describes the arrival and resettlement of asylum-seekers as "the ultimate wedge issue" in the 2017 election, pitting Chancellor Merkel's supporters against those who consider her refugee admissions economically, politically or socially "irresponsible" $(2016,591)$. Though Merkel's Christian Democratic Union (CDU) and their sister Christian Social Union party (CSU) stabilized a parliamentary majority in coalition with the Social Democratic Party (SPD), the antiimmigration Alternative fur Deutchland (AfD) was "the big winner" and gained about 1.2 million votes from former non-voters (Dostal 2016, 600). Refugee issues also have upset the traditional CDU/CSU federal alliance. Hailing from the socially conservative Bavarian heartland, CSU Interior Minister Horst Seehofer has demanded migrant restrictions partially in fear of losing votes to the AfD, both in the federal and upcoming state elections (Dostal 2017, 589). At the last minute, meetings with Chancellor Merkel led to the unveiling of a new "migration master plan" in July 2018. This plan details stricter border controls and more rapid deportation from so-called "transit centres" along the Austrian-Bavarian border, suggesting the establishment of "Anker" or "arrival, decision, return" centres throughout Germany in which the entire asylum procedure would take place (European Data News Hub 2018). Though its implementation remains to be seen, announcement of this plan demonstrates Merkel's willingness to compromise on issues of immigration and settlement to maintain a stable governing coalition.

\section{d. German Länder Governments}

Under Article 30 of Germany's Basic Law, Länder are responsible for “the exercise of state powers and the discharge of functions" determined at the federal level (Deutcher Bundestag 2014, 34). In immigration and settlement, Bokert and Bosswick note that Länder Ministries of the Interior "enact ordinances and administrative regulations for the respective state government to implement migration policy at the state level" $(2011,17)$. This includes legal residence and passport measures, the admission quota and residence status determinations, naturalization processes and deportations (Bokert and Bosswick 2011, 115). Länder are key partners in Germany’s National Integration Plan, which Schmidke 
finds was "designed to shift competence and responsibilities" in settlement to the state level $(2014,85)$. As he notes, this plan provided new funding streams in acknowledgement that Länder governments had been "more and more active" but formally unrecognized in education, housing and employment services for newcomers (Schmidke 2014, 86). To some extent, the devolution of responsibilities to German Länder has fostered innovation and responsiveness to place-specific challenges among Germany's diverse regions. Schmidke, for example, examines the state of North-Rhine Westphalia (NRW) as a "trendsetter" in legislation designed to promote equitable labour market access and education opportunities for newcomers, as well as in organizing state-level conferences across the country $(2014,87)$. In NRW, he describes state-level settlement policy as "pragmatic" in contrast to "the highly controversial and emotional debate" at the federal level (Schmidke 2014, 86). He also finds the NRW government has also strengthened third sector and community-level initiatives. In particular, he notes a project called Migrantinnenselbsthilfe or "migrant-self support groups", through which the Länder state funds legal, economic and public relations initiatives in partnership with the local third sector and newcomer communities (Schmidke 2014, 89).

Yet, literature also critically examines federal devolution of settlement to the German Länder. Bokert and Bosswick note that state-level settlement policy demonstrates show "complex conflict lines...among the various Länder...," as policies have been administered inconsistently from state to state (2007, 23). This is clearly illustrated in Bavaria, where the CSU has dominated state politics nearly unchallenged since World War II. Compared to relatively liberal states like North Rhine Westphalia (NRW), Bavaria has been particularly restrictive in settlement policies geared towards recent asylumseekers. The 2016 Bavarian Integration Act describes the state leitkultur or leading culture as "deeply rooted in the values and traditions of the common Christian West" (Bayerisches Staatsministerium Des Innern und für Integration 2016). Echoing divisive discourse at the federal level, the Bavarian state government promises to "support and challenge" those who settle in region, by "giving... support when necessary and demanding that they show initiative and take personal responsibility in addition to 
recognizing our laws and system of values” (Bayerisches Staatsministerium Des Innern und für Integration 2018). They expect newcomers of all ethnic and religious background to "identify with the basic rules of our society and live according to those rules," arguing that those "who cannot do this cannot expect any tolerance from us in return" and, even further, suggesting sanctions for those unable to integrate in this way (Bayerisches Staatsministerium Des Innern und für Integration 2018). Not only does this framework demand neoliberal self-reliance in settlement, but is underwritten by the framing of ethnic and religious Muslim minorities as threats to Bavarian society. As Funk notes, this discourse is "problematic, and terminally vague," reflecting regional social divides more clearly than any cohesive Bavarian identity $(2016,294)$. In a broader sense, inconsistencies at the state level are exacerbated by a lack of coordination between the Länder and Germany's federal government. Though Länder have gained greater responsibility in settlement, Blither and Ziebarth note that this devolution has a "non-binding character, with no real repercussions if established targets and goals are not met" $(2016,7)$. For this reason, reporting on settlement outcomes in 2012, the Federation of German Länder argued "it is imperative that the federal and regional governments pursue joint policy objectives" (BAMF 2012, 22). They also expressed funding concerns, arguing that sub-national governments can only "take more comprehensive structural measures in their own jurisdictions given greater share in the distribution of taxes" (BAMF 2012, 22). Much like in Canada, devolution in Germany appears to have brought "unfunded mandates" in settlement to sub-national stakeholders (Stasiulus et al. 2011).

\section{e. German Municipal Governments}

Schönwälder and Sohn characterize settlement in Germany as "overwhelmingly an urban phenomenon," particularly in large cities like Frankfurt, Stuttgart and Berlin, but also in secondary cities like Dortmund, Essen and Bremen (2005, 1443). Before the 2005 Immigration Act, Bokert and Bosswick note that settlement had largely been a local-level mandate upheld by cities and civil society (2011). To some extent, German's federal government has become more active both in their own role and in supporting municipalities since this time. However, according to Germany's Federation of Local 
Government Associations, "even though essential framework conditions are set by the federal government and the Länder," social inclusion still takes place "essentially at a local level” (BAMF 2012, 23). They note that in Germany's towns and cities “immigrants not only invigorate local cultural activities...they [also] contribute greatly to the economic prosperity and to securing the future viability of cities, districts and municipalities" (BAMF 2012, 23).

In addition to providing services for both German-born and newcomer residents, official municipal responsibilities in immigration and settlement include "operational duties" and local implementation of state and federal policy (Schneider 2012, 17). This agenda is particularly onerous for city-states like Hamburg, Bremen and Berlin, which undertake dual roles as municipalities and Länder. Given high population density, low housing availability and large flows of secondary migration, Katz et al. note that Germany's cities have "unique burdens" in absorbing and serving high numbers of recent asylum-seekers $(2016,2)$. However, they also note that German cities have also shown a "remarkable ability to innovate" in fostering social inclusion among growing newcomer resident populations (Katz et al. 2016, 3). Similarly, Focus Migration notes that German municipalities are uniquely capable of innovating "region-specific approaches" in language, education, labour market integration and, more broadly, in "unlocking the potential" of cultural diversity $(2012,6)$. In doing so, they suggest that German municipalities reframe newcomers as long-term members of German society rather than simply as "a buffer against the vagaries of the economic cycle" (Focus Migration 2012, 6).

In some cases, municipal settlement initiatives have been coordinated alongside Germany's upper-tier governments. In 1996, Hamburg and NRW Länder state governments persuaded Germany's federal government to explore social issues at the municipal level. The Socially Integrative Cities (SIC) project was thus born to address urban social exclusion among marginalized social groups through a federally-funded "integrated action plan" organized in dialogue with community residents (Lohr 2003, 3). Lohr notes that though this plan represents "a shining example of the meshing of three German political 
planes," it is primarily is directed by municipalities $(2003,5)$. Using SIC funding, the city of Stuttgart has developed renowned, uniquely inclusive programming by recruiting multi-lingual municipal employees, hiring interpreters and translators and focusing on cultural sensitivity in municipal services (Cities of Migration 2012; Focus Migration 2008; Siemiatycki and Triadafilopoulos 2010). Through these programs, Stuttgart's integration policies have aimed

“... to promote participation and equality of opportunity for people of different origins, to use cultural diversity to extend the personal and professional competence of all members of the international urban society and to promote peaceful co-existence among all groups of the population" (Focus Migration 2008, 5).

While partnership with upper-tier governments has clearly enabled cities like Stuttgart, municipal innovations in newcomer settlement are also undertaken at a grassroots level with newcomer communities and third sector organizations. In 2012, the Federation of German Municipalities found that municipalthird sector partnerships strengthen "civic involvement" and "intercultural cooperation" at a local level (BAMF 2012, 26). In particular, Katz et al. note that municipalities have relied on such partnerships while resettling recent asylum-seekers in high-density metropoles like Berlin and Hamburg $(2016,18)$. According to Schmidke, local governments also provide an "important institutional vehicle" for amplifying the voices of newcomer communities in German policymaking processes $(2014,90)$. He notes the importance of local integration advisory boards, made mandatory in municipalities with over 5000 registered newcomers, in which immigrants, refugees and third sector organizations are invited to forward interests and concerns in front of city council and other municipal administrators (Schmidke 2012, 18).

Though German municipalities are exemplary actors in newcomer social inclusion, much like in Canada relevant literature considers devolution within a larger political context. As Bokert and Bosswick note, before Germany's federal government formally recognized its role and responsibility as an immigrant-receiving country, their "political inertia" pressured municipalities to become active in newcomer settlement $(2007,22)$. Though the federal government "seems to have been mobilized" in the early 2000s (Bokert and Bosswick 2007, 22), and despite their increasing recognition of local level 
leadership since this time, literature suggests that municipalities could be better supported in their work with newcomer residents. In 2012, the Federation of German Municipalities noted budgetary challenges limit local settlement initiatives (28), a situation that has been exacerbated since recent increases in asylum-seekers resettling in German cities and towns. For example, Katz et al. note that the city-states of Berlin, Bremen and Hamburg receive "disproportionately more refugees per square kilometer" than other municipalities $(2016,1)$. They find that "the responsibilities facing these cities and municipalities are enormous: how to house, educate, train and integrate individuals from different cultures, with different education levels, who are often in need of emergency healthcare and special services" (Katz et al. 2016, 1). These significant challenges, paired with inconsistent federal support, may contribute to Ewert and Evers observation that in major German cities, there is a "stark discrepancy" between the pro-immigration discourse of municipal authorities and "migrants' experiences and conflicts at the local level" $(2013,19)$.

\section{f. The Third Sector in Germany}

In Germany, third sector organizations provide newcomer settlement services including counselling, language training, education, labour market and civic integration, housing and legal matters pertaining to residence and asylum. In particular, Shields et al. note innovations in Germany's third sector in personalized settlement plans, providing special courses for women and children and promoting social inclusion thorough sports (2016). Such services are offered both independently and as funded by uppertier governments and third party institutions. By briefly outlining the development of this diverse sector, we can better understand their unique successes and challenges as settlement service providers.

Zimmer et al. note that, since German monarchs of the Middle Ages relied on political support from church guilds and associations, the third sector has always been a "political social sphere" used by the federal state for "societal integration, political steering and conflict resolution" $(2004,683)$. For these reasons, Anhier and Siebel find that Germany's third sector “did not develop in antithesis to the state, but in interaction with it" $(1993,3)$. The largest third sector organizations are religious in nature, including 
the Christian Caritas and the Protestant Diakonie. These two Wohlfartsverbände or welfare associations emerged with industrialization in the late $19^{\text {th }}$ century, providing social services but also soothing social upheaval in an era of increasing economic polarization (Anhier and Siebel 1993). Other major organizations similarly organized along "religious, ideological or party lines" include the Catholic Red Cross, Jewish ZWST, the Social Democratic Workers Welfare Association and the non-partisan Parity organization (Zimmer et al. 2004, 685). These large welfare associations were significantly strengthened in the 1960s, when the German government granted them a special "subsidiary" status which effectively guaranteed federal funding (Zimmer et al. 2004, 685). Anhier and Siebel describe the subsidiary system as derived from "the principle of Gemeinwirtshaft, or communal economy," featuring non-market, noncompetitive delivery of social services $(1993,7)$. However, literature presents mixed views on the resulting system. Ahnier notes that it was often criticized as "corporatist, inflexible and inefficient" (1999, 42), and Zimmer notes that the closeness of welfare associations to the German government led to a "deep crisis of legitimacy" and distancing from client communities $(1999,42)$. Yet, others view welfare associations as a "protected space of private action for public benefit...," particularly from fascist or communist state domination (Anhier 2009, 51). For better or worse, state support shaped large welfare associations into the primary social service providers of postwar Germany.

Today, Germany's large welfare associations operate as mainstream agencies, with settlement services composing a small part of their larger mandate in social services. Funded by federal and state governments, churches, private donations and EU grants, they provide information, referral and aid in housing, education and employment and anti-racism advocacy. They also provide the bulk of government-funded integration courses (Bauder and Jayaraman 2014). Since 2015, these welfare associations have been particularly challenged to support asylum-seekers arriving in large numbers. Caritas, for example, provides urgent care in accommodation and medical needs, as well and medium and long-term support in language, employment and legal counselling in 568 facilities across the country 
(Caritas 2017). Welfare associations are critically affected by Germany's shifting social and economic paradigms. As part of a broader shrinking of the German welfare state throughout the 1980s and 1990s, the "subsidiary principle" privileging welfare associations was dissolved and competition introduced into Germany's third sector. At the same time, Bokert and Bosswick also note "substantial federal cuts" for third sector organizations in settlement $(2011,117)$. Despite these shifts, Bauder and Jayaraman find that a privileged legacy has helped welfare associations maintain a "near monopoly" on settlement services (2014, 181). Nonetheless, small and medium-sized unaffiliated immigrant and refugee-serving organizations have increasingly emerged since the late 1980s. Alongside welfare associations, Germany's National Integration Plan recognizes these Verein or registered voluntary institutions including churches, community organizations, sports, educational, cultural and youth bodies, women's groups and neighborhood projects as critical to "promoting integration at a local level on a person to person basis" (BAMF 2005, 3). Bauder and Jayaraman recently estimated that 6000 registered third sector organizations exist in Germany, "formed around shared ethno-specific or national identities and by professional associations of teachers, lawyers or social workers, with mandates ranging from providing language training, to education for children and youth, and professional training for adults" $(2014,181)$.

Among the many third sector organizations that compose Germany's settlement sector, literature recognizes the particular role of migrant-led organizations (MOs) formed around shared ethnicity, religion and hometown. MOs arose in the 1980s to provide education, employment and housing to guest workers in Germany. While Italian and Yugoslav MOs used to dominate the sector (Schmitter Heisler 1986), today the largest are Islamic and Turkish organizations including the Turkish-Islamic Union for 
Religious Affairs, Association of Islamic Cultural Centers, the Islamic Community Mili Gorus, the Association of Alevi Communities and the Islamic Council among others. Literature presents a range of opinions relating to the role of these institutions in newcomer settlement and social inclusion. Mueller, for example, suggests that some MOs help newcomers in Germany to "assert their identities both as Turks and Muslims" but they "do not emphasize integration," ultimately furthering social exclusion $(2005,424)$. Yükleyen and Yurdakul emphasize diversity among MOs, in they that "may contribute to integration or they may contribute to isolation" as a result of differing attributes, attitudes and resources $(2011,81)$. For Gedik, MOs help newcomers to "reconfigure their polyvalent political, religious and ethnic identities," in simultaneously strengthening their local and transnational social networks $(2011,157)$. Through a case study of Turkish hemsehri or hometown organizations, he finds that "migrants in Germany...begin to structure their own relationships with the help of a common space... and further develop relationships to German society at various levels" (Gedik 2011, 190). Similarly, Amelina and Faist find that MOs facilitate social inclusion as a two-way process of "public negotiation of cultural and identity boundarydrawing," by advocating for client needs while remaining receptive to German government and society $(2008,94)$. For example, Musch details MOs formal involvement in settlement policymaking through the 2006 German Islam Conference, a landmark event institutionalizing the relationship between newcomer communities and multiple tiers of German governance (2011). 


\section{Chapter 5: Themes in Germany's Third Sector in Settlement and Cross-National Discussion}

This MRP first outlined the structure and landscape of the Canadian third sector in settlement, pulling key themes from available literature in this sphere. Having outlined the German third sector, it will now recall the Canadian context by highlighting themes, commonalities and divergences between the two. As aforementioned, the purpose of cross-national discussion is not to evaluate settlement and social inclusion objectively. Instead, and in light of the shared neoliberal policy context, this discussion and analysis will critically reconsider newcomer social inclusion in both Canada and Germany by better understanding common challenges, strengths and distinctions.

\section{a. Neoliberalism, devolution and "responsibilization" in the third sector}

Public policy in Canada and Germany has been influenced by neoliberal frameworks since the 1980s. While this shift has affected social services overall, this study has focused on neoliberal policy in newcomer settlement. In both countries, as the welfare state is further defunded, the third sector develops into a key service provider for immigrants and refugees. Lowe et al. term this phenomenon "responsibilization," through which "services and care previously provided by the state are being increasingly downloaded onto the local government, non-profit providers, communities and families" $(2016,19)$. As aforementioned, many examine third sector responsibilization in Canada as the emergence of a "shadow state" (Sadiq 2004, Evans and Shields 2000, Evans et al. 2005). This literature review reveals similar responsibilization of the third sector in Canada and Germany. 
As German government "dedicated only minimal attention to formal integration and inclusion efforts" for postwar guest workers viewed as temporary visitors (Boyer and Pardini 2013, 15), third sector welfare associations oversaw critical settlement aid (Schmitter Heisler 1986, 84). Today, the German third sector remains "responsibilized" in settlement, and Friedrichs and Klöckner relate their expanding role to government efforts to "reduce their provisions" in welfare state since the 1980s $(2009,104)$. In both Germany and Canada, literature suggests that neoliberal restructuring in third sector settlement organizations has emerged through New Public Management governance. For example, Zimmer finds that in the context of new competitiveness and limited funding, German third sector organizations “increasingly have become more businesslike, introducing management and marketing techniques, and replacing social workers with business managers" $(1999,45)$. As a consequence of this shift, he suggests that Germany's third sector is experiencing a "crisis of identity... because they have turned into a social services industry, putting a high emphasis on efficiency" (Zimmer 1999, 45). As little literature is available on the subject, the extent to which NPM restructuring affects the capacity of the German third sector to provide settlement services, administer government integration programs and advise policymakers is a particularly interesting avenue for future research.

Several recent studies suggest that third sector organizations have been particularly responsibilized in servicing non-status migrants without residence rights in Germany, including those with failed refugee status claims. Castañeda, for example, examines third sector healthcare provision for non-status migrants in Berlin, finding that "NGO intervention functions to ease suffering when the government has failed to ensure basic human rights for everyone within their borders..." $(2007,285)$. 
However, she also finds that "as NGOs and activists take on the responsibility for medical aid, the issue essentially becomes privatized, producing a precarious situation in which the state is no longer liable for certain populations" $(2007,19)$ To this end, Bendel asks "a key and cross-cutting question: How far does it make sense to privatize integration measures within these crucial state policies that are so important for integration?" $(2014,21)$. Examining aid provided to non-status newcomers by Diakonie and Caritas, Badikyan adds that while these individuals are entitled to medical aid, schooling and work remuneration, "controlling policies and laws" on reporting non-status newcomers to German authorities discourages them from seeking these services $(2014,35)$. For Badikyan, reliance on the third sector to provide such services reflects "wanted versus unwanted migrants and hence selective investment" by the federal government $(2014,35)$. This, too, presents similarities to the Canadian case, where several scholars link neoliberal federal policies to a binary of "deserving" and "non-deserving" newcomers based on their perceived economic boon or burden to Canadian society (Arat Koc 1999; Barass and Shields 2017).

In the context of rising numbers of asylum-seekers since 2015, the German case is unique in that that third sector responsibilization has occurred alongside responsibilization of civil society more generally. The federal German government promotes "joint civic commitment” of Germans and newcomers as central to integration efforts (BAMF Website). Bock notes that German volunteerism peaked in 2015, as between 800,000 and one million Germans took part in third sector or self-organized resettlement initiatives $(2018,11)$. Funk describes these efforts as "vast, polyphonic and everywhere" (2016, 292). Bock focusses on volunteerism among minorities in Germany, and Muslims in particular, noting their engagement was fuelled by efforts "to demonstrate their progress with "integration," 
showcase their interest in political participation and confront Islamophobia and the processes of exclusion" $(2018,12)$. While widespread volunteerism provides an optimistic counter-narrative to growing anti-refugee sentiment within Germany's far right, Karakayali and Keist note that "it is important that volunteers do not substitute state obligations" $(2014,66)$. Similarly, Hinger questions "where to draw the line between volunteers lending the necessary support and the assumption of core state responsibilities" $(2016,86)$. Badikyan argues that as volunteerism better enables the German third sector to aid marginalized populations, "the more these allegedly temporary services become the norm" (2014, 284). In other words, not only is it unsustainable to depend on civil society for professional settlement services, but volunteerism further engrains the third sector as a "shadow state" if it lessens government accountability in newcomer settlement (Shields and Evans 2000, Sadiq 2004; Stasiulus et al. 2011).

\section{b. Precarity in a "two-tier" settlement sector}

In Canada, the third sector is mainly composed of universal, multi-service and ethno-specific organizations, while in Germany the sector includes large welfare associations, smaller, newer settlement agencies and ethno-specific migrant organizations. Both countries are home to "two-tier settlement sectors" (Sadiq 2004), composed of smaller, ethno-specific and immigrant-led agencies and larger, multiservice organizations. While a diverse settlement sector can strengthen its response to social exclusion, in both Canada and Germany resources and federal support are divided unevenly between different types of organizations. As Bauder and Jayaraman note, "the phenomenon of small, resource-strapped organizations" is evident in both Canada and Germany $(2014,181)$. This has led to particular forms of precarity in small and ethno-specific organizations critical to social inclusion in both countries. 
To some extent, literature suggests that funding difficulties at all levels of German third sector organizations providing settlement services. As Castañeda notes, "while the NGO sector in Germany has always been charged with implementing social services, this situation reflects a reliance on humanitarianism and good will, rather than providing adequate funding and ensuring access" $(2007,285)$. Jayaraman and Bauder examine shared experiences of employment precarity among Canadian and German third sector settlement staff, who are themselves predominantly racialized and immigrant women (2014). Yet, despite the introduction of competition into the German third sector, Bode finds that many large welfare organizations have "withstood the test of New Public Management... in realizing economies of scale and accepting less comfortable, albeit still "corporatist" contracts" $(2006,350)$. For example, Diakonie and Caritas enjoy relatively consistent funding from the German government and the EU, alongside private and church donations, receiving about 20 percent of all government funding for newcomer settlement initiatives in 2015 (Mattes 2017, 48). Thränhardt similarly finds that these agencies absorb much of the government settlement funding in Germany, as "state and local authorities...feel they have fulfilled their responsibilities for migrants through Wohlfartsverbande" $(1989,15)$. Due to their extensive infrastructure and longstanding government funding relationships, Bauder and Jayaraman describe welfare associations as the "top tier" of the German settlement sector $(2014,181)$.

For Bauder and Jayaraman, the "bottom tier" of Germany's settlement sector includes smaller, newer agencies and migrant-led religious and ethno-specific organizations. As opposed to the large welfare organizations, here "gaps in basic infrastructure, stable funding and capacity building" have even further impacted "their ability to offer full-time jobs and attract and retain well-qualified staff" (Bauder 
and Jayaraman 2014, 181). Castañeda, too, notes that smaller and newer organizations in Germany are "at a distinct disadvantage" in seeking to secure government funding and contracts, as "they have not yet proven they are worthy of funding... at various political levels" $(2007,116)$. For example, MOs are recognized as "absolutely crucial" agents in German settlement, and were for the first time included as stakeholders in the National Integration Plan (BAMF 2007, 2). However, they are not widely supported by the German federal state and have never received the same institutionalized status as welfare associations. Yükleyen and Yurdakul suggest that government funders particularly distance themselves from MOs perceived to be "part of political Islam," such as the Islamic Community Mili Gorus (2011, 73). Sezgin and Dijkzeul find that the survival of Mili Gorus thus "highly depends" on member donations and volunteerism within newcomer communities themselves $(2014,15)$. Musch, too, notes that MOs often perceive that they "lack the financial means" to effectively serve newcomers to Germany (2012, 80). For Bock, their underfunding is problematic given increasing workloads in settlement and in addressing Islamophobia and the "inadequacy of public institutions" to meet the needs of recent asylumseekers in Germany $(2018,12)$. Similarly, Yükleyen and Yurdakul find that MOs are uniquely capable of bridging newcomer communities to German society, if only the state could empower them by better “providing funding and maintaining dialogue" $(2011,81)$.

For lack of public funding, like in Canada, literature suggests that small and migrant-led organizations in Germany rely on partnership with larger welfare associations. Bauder and Jayaraman note over $30 \%$ of Caritas and Diakonie federally-funded projects were undertaken in partnership with migrant-led organizations such as Africa Positive and the Association of Islamic Cultural Organizations 
$(2014,181)$. Similar to Canada, it appears that though such partnerships have potential to further the reach of the third sector, they are limited by asymmetrical power dynamics. Thränhardt notes that where smaller and migrant-led agencies in Germany become dependent on welfare associations, "it may constitute a special sort of bossism merging into clientelistic structures" wherein the latter have more power to direct the mandate and mission of shared projects $(1989,15)$. While little literature is available on the specifics of German inter-organizational dynamics, the shared precarious structure of two-tiered settlement sectors in Canada and Germany presents an interesting cross-national case study for future analysis.

\section{c. State funding and third sector autonomy}

In Germany, like in Canada, literature suggests that third sector political autonomy is linked third sector funding dependencies. Badikyan finds that faith-based welfare associations, long criticized for their closeness with the German state, actually maintain independence through church support and that of “mighty global networks" which extend beyond the German borders $(2014,44)$. Yet, she notes that unaffiliated, smaller Verein organizations more dependent on state funding sacrifice "control over the codes of conduct that define the main principles of humanitarianism- impartiality, neutrality and independence" (Badikyan 2014, 43). For example, a respondent from a German anti-racism organization noted that non-reporting of non-status client information problematized application for funding contracts. Another noted that "if we want funding from the government, we can talk about victims of trafficking or rejected asylum-seekers: this is the closest we can get to the topic of [irregular migration]" (Badikyan 2014, 45). Badikyan ties this apparent advocacy chill to government aims of deterring irregular migration, as third sector organizations determined "not to be cut off from financial support" disrupt access to 
critical services for non-status migrants in Germany $(2014,46)$. Yet, each agency responds to this situation differently. Castañeda finds that some organizations, such as the Berlin Office for Medical Aid for Refugees, "fundamentally reject" state funding to maintain organizational autonomy $(2007,261)$. Migrant-led organizations of Islamic and Turkish origin receive very little government funding and thus are not beholden to the political aims of government donors, though Sezgin and Dijkzeul note that programming is "simply based on the membership (donor) interests" instead $(2014,15)$. Overall, advocacy chill appears to similarly threaten third sector autonomy in both Germany and Canada, aligning organizational activities with funder political and economic prerogatives rather than client needs.

\section{d. Strategies to strengthen the third sector}

In both Canada and Germany, third sector organizations are the lowest tier of authority within a multi-level political structure, yet remain critically affected by neoliberal policies engineered in upper-tier governments. However, both third sectors have also proven to be innovative and resilient agents within this system. In Canada, this is illustrated in coalitions both within and beyond the third sector, as well as through the strengthening of municipal networks. In Germany, literature suggests similar avenues for capacity-building have been explored, as well as additional strategies at the supranational level.

To some extent, literature points to increasing inclusion of the third sector in the drafting of German settlement policy. As Bokert and Bosswick note, attending practitioner meetings and national hearings on migration, though "not always by invitation...," has become "a very relevant part" of third sector activities $(2011,116)$. Several note the Süssmuth Commission, an independent integration advisory 
group formed in 2000 and headed by parliamentary leader Rita Süssmuth, as a landmark of third sector policy consultation. Schneider and Scholten suggest that the Commission relied on the testimony of third sector practitioners to rethink a new frame for immigration that "was both more inclusive and universalist" $(2015,85)$, and Bokert and Bosswick note that the Commission gave "special attention" to proposals forwarded by the third sector through the 2001 Steering Migration and Fostering Integration report $(2011,116)$. Literature also notes increasing inclusion of migrant-led and minority religious organizations in policymaking forums. To this end, Musch examines the extent to which the 2006 National Integration Summit and German Islam Conference enabled migrant associations in Germany "to voice their opinions on issues that concern them as citizens or residents" $(2012,74)$. Before 2006 , he notes that MOs has been largely excluded from policy consultation, applying "external pressure" instead through larger welfare associations (Musch 2012, 75). For the first time, Musch finds these landmark conferences formally involved MOs in dialogue with upper-tier government in "processes of policy formulation and implementation" $(2012,75)$.

Like in Canada, despite the challenges of a neoliberal policy context, Germany's settlement sector has amplified its voice in consultative forums and strengthened its overall capacity through coalition-forming initiatives. Halm notes that German umbrella organizations coalesce to pool scarce resources and share knowledge $(2017,110)$, and Bokert and Bosswick add that they also arose from "the need to support policy proposals with a broad basis of civil society," in promoting anti-racist and human rights ideologies $(2011,118)$. Bokert and Bosswick note the particular importance of the Federal Association of Non-Statutory Welfare, an umbrella organization encompassing the major welfare 
associations, which argues for "equal opportunities, social justice and civil participation" as cornerstones of a "common rights approach" to settlement $(2011,118)$. MOs, and in particular Muslim and Turkish organizations, form their own coalitions such as Coordination Council of Muslims in Germany, the Islamic Council and the Association of Islamic Cultural Centers. In both Canada and Germany, it appears that the third sector has responded to advocacy chill and upper-tier government austerity by enhancing sectoral coordination at a grassroots level.

In Canada, the importance of municipalities in settlement initiatives has been well-established (Stasiulus et al. 2011; Biles et al. 2011; Mwaringa 2002). Interestingly, in Germany, literature also illustrates localized alliances between the third sector and municipal governments. Bokert and Bosswick find that such partnerships addressed newcomer settlement "long before the issue reached the national agenda" and also helped to eventually "trigger responses from the federal government" $(2011,118)$. Hinger examines the link between sub-national governments and the third sector in German asylum policy, finding that while policy is technically determined at the federal level, in practice it is a "local negotiation" $(2016,85)$. Schmidke similarly examines local level government in Germany and Canada as "important laboratories for deliberating, developing and implementing immigration and, in particular, integration policies" $(2014,77)$. In both countries, he finds there has been "substantial strengthening of place-based approaches to governing migration," as by sub-national tiers of governance foster capacitybuilding in local third sector organizations $(2014,93)$. For Schmidke, a major difference between Canada and Germany is that Canadian municipalities are constrained by "limited jurisdictional and fiscal powers," while in Germany, localized settlement initiatives can be emboldened through supranational European Union funding and support $(2014,94)$. 


\section{e. Centralization of policymaking power in settlement}

Despite the apparent devolution of settlement service provision to Germany's third sector, and despite the partnerships which have strengthened local initiatives, like in Canada literature suggests that the German federal government remains at the centre of settlement policymaking. For example, Schneider and Scholten note that the Süssmuth Commission report, guided by the expertise of many third sector advocates, "ended up playing barely any role at all" in the 2005 Immigration Act, as "policymaking followed a familiar path with the main actors retreating to their 'old' frames on immigration and integration" $(2017,85)$. For them, resulting legislation ultimately "failed both to break with the exclusionary model of immigrant integration and to reconceptualize the German migration policy framework" (Schneider and Scholten 2017, 87). Musch similarly finds that though MOs gained a seat at the table during the National Integration Conference and the German Islam Conference, "the involvement of migrants and their associations in policymaking processes was rather symbolic in nature" $(2012,86)$. She ultimately concludes that "governmental actors played the steering role" in terms of structures, procedures and policy formation both during and after the conferences (Musch 2012, 87). Examining Germany's municipal integration advisory boards, Schmidke similarly finds that while these forums have fostered political participation among newcomer communities, they ultimately comprise "a limited, consultative role" in settlement policy $(2014,90)$. Though Schmidke suggests that the EU serves as an “enabling" agent by funding municipal initiatives in some cases $(2014,91)$, Menz finds that that the German state has been "remarkably successful" in shielding national policy from broader EU regulation (2011, 458). Despite supranational support, he thus concludes that "non-state actors" in the third sector and within the European Union have limited influence on national policy (Menz 2011, 458).

Similar to Canada, it ultimately appears that Germany has adopted a system of "centralized decentralization" which extends state control of settlement policymaking while relying on the third sector, communities and newcomers to minimize state spending (Evans et al. 2005, 73). For example, Bokert and Bosswick note that third sector funding cuts and the simultaneous implementation of mandatory 
integration courses in the early 2000 s signify "a shifting of integration measures from the welfare policy context to one of control" $(2011,116)$. Using this brief literature review as a foundation, further crossnational study might illuminate the effect of this shared neoliberal policy orientation on patterns and experiences of social exclusion among immigrants and refugees in Germany and Canada. 


\section{Conclusion}

This brief overview of settlement, social inclusion and the third sector in Canada and Germany has focused on the ways that newcomer-serving organizations are influenced by a neoliberal operating environment and the multiple stakeholders that inhabit it. In doing so, it has demonstrated the complexity and diversity of actors involved in settlement policy and programming in multi-tier, federalist systems of governance. The aim of this Major Research Paper was not to definitively assess the Canadian or German third sector, nor to suggest that one should serve as a blueprint for the other. Given noted literature gaps, its objective has been to build a foundation for further research and establish grounds for continued knowledge sharing between these two important newcomer-receiving countries.

Around the world, neoliberal shifts during the 1980s have been institutionalized as political and economic doctrine. In Canada and Germany, the erosion of the welfare state has increased the responsibility of municipalities, communities and newcomers themselves in settlement. At the same time, funding austerity and the implementation of New Public Management governance has constrained third sector capacity to respond to social exclusion among newcomer populations. The task faced by the third sector in attending to increasing numbers of immigrants and refugees comprises not only direct service provision, but equally includes broader political advocacy and anti-racism initiatives key to reducing racial discrimination. In both countries, too, the impact of neoliberal policy has not been uniform among third sector organizations. It appears most significant among new, small, ethno-specific or migrant-led organizations, whose operations in outreach among newcomers further removed from mainstream society are made precarious as a result. Nonetheless, in both Canada and Germany the third sector has actively 
responded to meet the needs of clientele populations by pooling resources internally and in partnership with the government, particularly at the municipal level. In the context of increased asylum-seeking in recent years, literature suggests that the German third sector has particularly relied on volunteerism among civil society and, to some extent, on support from the European Union. However, in both countries the federal government appears to maintain centralized policymaking power in newcomer settlement. Despite gaining a foothold as consultative bodies, third sector organizations have not been fully enabled to translate their extensive and valuable community knowledge into government policy. Yet, as rightwing, nationalist and anti-immigrant political voices strengthen in both Europe and North America, effective third sector representation of client communities in governmental forums is more important than ever. In light of Germany's recent experience with asylum-seekers, and as increasing numbers of illegalized migrants arrive at Canada's border with the United States, this a key lesson for stakeholders in both countries. In Canada and Germany, this review finds that shared challenges in the third sector are linked to funding shortages but, more broadly, to power dynamics that still favor federal government's priorities over those of immigrant and refugee communities. Strengthening each third sector would thus require a deeper, structural reconsideration of contemporary settlement governance, as well as the neoliberal policy context in which these processes take place.

For Evans and Shields, a significant effect of neoliberal austerity in newcomer settlement is that third sector agencies rarely have the resources to conduct their own research $(2014,124)$. Yet, in a system characterized by centralized policymaking power, third sector agencies also note that comprehensive, policy-centred research allows them to "enhance the validity and effectiveness of their voice" by 
convincingly communicating client needs to government policymakers through "evidence-based advocacy" (Evans and Shields 2014, 125). Despite major historical, geographical and sociological differences between Canada and Germany, this report identified a number of shared themes in settlement, social inclusion and third sector initiatives in the context of neoliberal public policy. It is my hope that this study serve as a foundation for continued research in this field, and help to amplify third sector voice in partnership with their vibrant, diverse newcomer client communities. In particular, primary crossnational research of the lived experience of third sector settlement services in a neoliberal policy context would better incorporate newcomer voices into future studies. Every tier of national government, third sector organizations large and small, and host societies themselves stand to benefit where social inclusion can be more effectively achieved among newcomers in Canada and Germany.

\section{References}

Acheson, N., \& Laforet, R. (2013). The Expendables: Community Organizations and 
Governance Dynamics in the Canadian Settlement Sector. Canadian Journal of Political Science 46 (3), 597-616.

Alba, R., \& Foner, N. (2014). Comparing Immigrant Integration in North America and Western Europe: How Much Do the Grand Narratives Tell Us. International Migration Review 48 (1), 263-291

Amelina, A., \& Faist, T. (2008). Turkish Migrant Organizations in Germany: Between Integration Pressure and Transnational Linkages. Revue européenne des migrations internationales 24 (2), $91-120$

Amir-Mozami, S. (2005). Buried Alive: Multiculturalism in Germany. Institute for the Study of International Migration Review 16, 22-23

Anhier, H (2009). Third Sector Independence and the Subsidiary Principle: A Comparative Historical Essay. In The First Principle of Voluntary Action eds. Matthew Smeardon. (Working Paper 3). London: The Baring Foundation, 51-67

Anhier, H., \& Siebel, W. (1993). Defining the Non-Profit Sector: Germany. (Johns Hopkins Comparative Non-profit Sector Project Working Paper 6). Baltimore: The Johns Hopkins Institute for Policy Studies. Web: https://www.researchgate.net/publication/30530189 The nonprofit sector in Germany

Arat-Koc, S. (1999). Neo-liberalism, State-Restructuring and Immigration: Changes in Canadian Policies in the 1990s. Journal of Canadian Studies 34 (2), 31-56.

Ashton, W., Pettigrew R.N. \& Galatsanou, E. (2016). Assessment of Settlement Services Systems in Western and Northern Canada: Perceptions of Settlement Provider Organizations. Canadian Ethnic Studies 48 (3), 69-89.

Badikyan, T. (2014). Organizational Support from Diakonie and Caritas to Irregular Migrants in Berlin, Germany (Master's Thesis). University of Oldenburg: EMMIR

Baines, D., Campey, J., Cunningham, I. \& Shields, J. (2014). Not Profiting from Precarity: The Work of Non-profit Service Delivery and the Creation of Precariousness. Just Labour: A Canadian Journal of Work and Society (22), 74-93.

BAMF. (2007). The National Integration Plan: Driver of Integration Policy. Web: https://ec.europa.eu/migrant-integration/index.cfm?action=media.download\&uuid=2A91BC23E195-CCE2-3F70DDECBCA02D10

BAMF. (2012). National Action Plan on Integration abridged press version. Web: https://www.bundesregierung.de/Content/DE/ Anlagen/IB/2012-01-31-nap-kurzfassung-presseenglisch.pdf?_blob=publicationFile

BAMF. (2016). Integration Act to support and challenge. Web: https:/www.bundesregierung.de/Content/EN/Artikel/2016/07 en/2016-05-25-integrationsgesetzbeschlossen_en.html

BAMF. (2018). Attendance and Costs. Web: http://www.bamf.de/EN/Willkommen/DeutschLernen/Integrationskurse/TeilnahmeKosten/teilnah mekosten-node.html 
BAMF. (2018). Local integration projects. Web:

http://www.bamf.de/EN/Willkommen/Integrationsprojekte/Engagement/engagement-node.html

Bartlett, S., \& McKitrick, A. (1999). The Collaboration Roundtable - Phase II: Outreach to Smaller Organizations. Victoria: Ministry Responsible for Multiculturalism and Immigration, Community Liaison Division. Web: https://www.mosaicbc.org/wp-content/uploads/2016/12/collaborationRoundtable-phasell.pdf

Bauder, H. (2008). Neoliberalism and the Economic Utility of Immigration: Media Perspectives of Germany's Immigration Law. Antipode, 40 (1), 55-78

Bauder, H., \& Jayaraman, R. (2014). Immigrant workers in the immigrant service sector: segmentation and career mobility in Canada and Germany. Transnational Social Review 4, (2/3), 176-192

Bauder, H., Lenard, P.T., \& Straehle C. (2014). Lessons from Canada and Germany: Immigration and Integration Experiences Compared. Comparative Migration Studies 2, (1), 1-7

Bayerisches Staatsministerium Des Innern und für Integration (2016). Bavarian Integration Act. Web: http://www.gesetze-bayern.de/Content/Document/BayIntG?AspxAutoDetectCookieSupport=1

Bayerisches Staatsministerium Des Innern und für Integration (2018). Making Bavaria Your New Home. Integration in Bavaria. Web: https://www.in.bayern.de/infos-migranten/heimatfinden/index.php.en

Bendel, P. (2014). Coordinating Immigrant Integration In Germany: Mainstreaming at the Federal and Local Levels. Brussels: Migration Policy Institute Europe.

Biles, J., Tolley, E., Andrew, C., Esses, V. \& Burnstein, M. (2011). "Integration and Inclusion in Ontario: The Sleeping Giant Stirs" in Integration and Inclusion of Newcomers and Minorities across Canada. Eds. John Biles, Meyer Burstein, James Frideres, Erin Tolley and Robert Vineberg. Montreal and Kingston: McGill-Queens University Press, 195-246.

Bisson, R. \& Associates. (2011). Final report: Research on settlement services available in French for Francophone newcomers to Ontario. Toronto: Ontario Ministry of Citizenship and Immigration. Web: http://www.citizenship.gov.on.ca/english/publications/francophone report/index.shtml\#executive -summary

Blither, J., \& Ziebarth, A. (2016). In it for the long run: Integration lessons from a changing Germany. (Integration Strategy Group Working Paper). Berlin: Deutsche Gesellschaft für Internationale Zusammenarbeit (GIZ) GmbH and German Marshall Fund of the United States. Web: http://www.gmfus.org/publications/it-long-run-integration-lessons-changing-germany

Bloemraad, I. (2005). Becoming A Citizen: Incorporating Immigrants and Refugees in the United States and Canada. Berkley: University of California Press

Bloemraad, I. (2013). The promise and pitfalls of comparative research design in the study of migration. Migration Studies 1 (1), 27-46 
Benzie, R. (2018, July $5^{\text {th }}$ ). Ford government is ending co-operation with Ottawa on resettlement of asylum-seekers. Toronto Star. Web: https://www.thestar.com/news/queenspark/2018/07/05/fordgovernment-is-ending-cooperation-with-ottawa-on-resettlement-of-asylum-seekers.html

Bock, J-J. (2018). State Failure, Polarization, and Minority Engagement in Germany's Refugee Crisis. International Journal of Politics, Culture and Society 31, 1-22

Bode, I. (2006). Disorganized welfare mixes: voluntary agencies and new governance regimes in Western Europe. Journal of European Social Policy 16 (4), 346-359

Bokert, M., \& Bosswick, W. (2007). Migration Policymaking in Germany - between national reluctance and local pragmatism? (IMSCOE Working Paper 20). Rotterdam: International Migration, Integration and Social Cohesion in Europe. Web:

http://citeseerx.ist.psu.edu/viewdoc/download?doi=10.1.1.474.3060\&rep=rep1\&type=pdf

Bokert, M., \& Bosswick, W. (2011). The Case of Germany. in Migration Policymaking in Europe: The Dynamics of Actors and Contexts in Past and Present eds. Giovanna Zincone, Rinux Penninx and Maren Bokert. Amsterdam: Amsterdam University Press, 95-129

Boyer, S., \& Pardini, V. (2013). Current Immigration and Integration Debates in Germany and the United States: What We Can Learn From Each Other. Washington: Hienrich Böll Foundation. Web: https://www.boell.de/sites/default/files/2013-08-Boyer-Pardini_Immigration-andIntegration.pdf

Bradford, N. \& Andrew, C. (2010). Local Immigration Partnership Councils: A Promising Canadian Innovation. Ottawa: Citizenship and Immigration Canada. Web: http://p2pcanada.ca/wp-content/blogs.dir/1/files/2015/09/Local-Immigration-PartnershipCouncils-A-Promising-Canadian-Innovation1.pdf

Cabral, V. (2000). Settlement Services for Newcomers and Access to Family Services. Multicultural Coalition for Access to Family Services. Web: http://atwork.settlement.org/downloads/Access_Family_Services.pdf

Campbell, L. (2012). Multikulti Ist Doch 'Ne Erfolgreiche Realität: Why Tolerance is Vital for German Economic Growth. Boston College International and Comparative Law Review 35 (2), 449-480

Canadian Council for Refugees. (2011). Refugee Integration: Key concerns and areas for further research. Montreal: Canadian Council for Refugees. Web: http://ccrweb.ca/files/refugeeintegrationresearch-report.pdf

Caritas (2017). What does Caritas do for refugees in Germany? Web: http://www.caritasgermany.org/focus/currentissues/what-does-caritas-do-for-refugees-in-germany

Castañeda, H. (2007). Paradoxes of Providing Aid: NGOs, Medicine, and Undocumented Migration in Berlin, Germany (Doctoral Dissertation). University of Arizona, Tuscon. Web: https://repository.arizona.edu/bitstream/handle/10150/195410/azu etd 2125 sip1 m.pdf?sequen $\mathrm{ce}=1$

Cities of Migration (2012). Good Ideas from Successful Cities: Municipal Leadership on Immigrant Integration. Toronto: Maytree. Web: http://citiesofmigration.ca/wpcontent/uploads/2012/03/Municipal_Report_Main_Report2.pdf 
Dostal, M. (2017) The German Federal Election of 2017: How The Wedge Issue of Refugees and Migration Took the Shine off Chancellor Merkel and Transformed the Party System. The Political Quarterly 88 (4), 589-602

Deutche-Presse Agentur (July 5 ${ }^{\text {th }}$, 2018). What's in German rebel minister Seehofer's migration master plan? European Data News Hub. Web: https://www.ednh.news/whats-in-german-rebel-ministerseehofers-migration-master-plan/

Deutche Bundestag. (2014). Basic Law for the Federal Republic of Germany. Trans. Christian Tomuschat, David Curry and Donald Kommers. Web: https://www.btgbestellservice.de/pdf/80201000.pdf

Eurostat (2017). Asylum in the EU Member States: 1.2 million first time asylum-seekers registered in 2016." Eurostat, March $16^{\text {th }} 2017$. Web: http://ec.europa.eu/eurostat/documents/2995521/8001715/3-26042017-APEN.pdf/05e315db-1fe3-49d1-94ff-06f7e995580e

Eurostat (2017). Asylum decisions in the EU. EU Member states granted protection to more than 700,000 asylum seekers in 2016." Eurostat, April 26 ${ }^{\text {th }} 2017$. Web: http://ec.europa.eu/eurostat/documents/2995521/8817675/3-19042018-AP-EN.pdf/748e8fae$2 \mathrm{cfb}-4 \mathrm{e} 75-\mathrm{a} 388-\mathrm{f06f6ce} 8 \mathrm{ff5} 5$

Evans, B., Richmond, T. \& Shields, J. (2005). Structuring Neoliberal Governance: The Nonprofit Sector, Emerging New Modes of Control and the Marketisation of Service Delivery. Policy and Society 24 (1), 73-97.

Evans, B. \& Shields, J. (2014) Non-profit Engagement with provincial policy officials: The case of NGO policy voice in Canadian immigrant settlement services. Policy and Society 33, 117-127.

Ewert, B., \& Evers, A. (2013). The Context for Social Innovation-Policy Orientations in Berlin and Kreuzberg-Friedrichshain, Germany. (Work Package 4). Nijmegen: Welfare innovations at the local level in favor of cohesion. Web: http://www.wilcoproject.eu/wpcontent/uploads/2014/01/WP4-Berlin.pdf

Friedrichs, J., \& Klöckner, J. FBOs and Social Exclusion in Germany. in Faith-Based Organizations and Social Exclusion in European Cities eds. Danielle Dierckx, Jan Vranken and Wendy Kerstens. Leuven: Uitgeverji Acco, 69-135

Focus Migration (2008). Integration policy at a regional level in Germany. (Policy Brief 10). Hamburg: Hamburg Institute of International Economics. Web: www.bpb.de/system/files/pdf/HEJLVH.pdf

Funk, N. (2016). A spectre in Germany: refugees, a 'welcome culture' and an 'integration politics.' Journal of Global Ethics 12 (3), 289-299

Garkish, M., Heidingsfelder., J. \& Beckmann, M. (2017). Third Sector Organizations and Migration: A Systematic Literature Review in View of Flight Migration and Refugee Crises. Voluntas 28, $1839-1880$ 
Gedik, E. (2011). Migrant Organizations in Turkey and Germany: Local, Transnational and Global Contexts of Kurdish- Alevis from Varto, Turkey. Urban Anthropology and Studies of Cultural Systems and World Economic Development 40 (1/2), 151-204

Germain, A. \& Trinh, T. (2011). Immigration in Quebec: Profile and Players. In Integration and Inclusion of Newcomers and Minorities across Canada. Eds. John Biles, Meyer Burstein, James Frideres, Erin Tolley \& Robert Vineberg. Montreal and Kingston: McGill-Queens University Press, 195246.

Government of Canada. (2017). Supplementary Information 2018-2020 Immigration Levels Plan. Web: https:/www.canada.ca/en/immigration-refugees-citizenship/news/notices/supplementaryimmigration-levels-2018.html

Government of Canada. (2017). 2017 Annual Report to Parliament on Immigration. Web: https://www.canada.ca/en/immigration-refugees-citizenship/corporate/publicationsmanuals/annual-report-parliament-immigration-2017.html\#aboutImmCan

Good, K. (2007). Urban Regime Building as a Strategy of Intergovernmental Reform: The Case of Toronto's Role in Immigrant Settlement. Saskatoon: CPSA Annual Conference, May 30thJune 1st 2007. Web: https://www.cpsa-acsp.ca/papers- 2007/Good.pdf

Goodman, S.W. (2010). Integration Requirements for Integration's Sake? Identifying, Categorizing and Comparing Civic Integration Policies. Journal of Ethnic and Migration Studies 36 (5), 753-772

Green, S. (2005) Immigration and Integration Policy: Between Incrementalism and Non-decisions. In Governance in Contemporary Germany: The Semi-sovereign State Revisited eds. Simon Green and William E. Paterson. Cambridge: Cambridge University Press.

Halm, D. (2017). Access to Religious and Ethno-cultural Communities in Germany. in Structural Context of Refugee Integration in Canada and Germany eds. Annette Korntheuer, Paul Pritchard and Debora B. Maehler. Liebniz: Leibniz Institute for the Social Sciences, 107-113

Hinger, S. (2016). Asylum in Germany: The Making of the "Crisis" and the Role of Civil Society. Human Geography 9 (2), 78-88

Hübschmann, Z. (2015). Migrant Integration Programs: The Case of Germany. (Global Migration Research Paper 11). Geneva: Global Migration Centre. Web: http://repository.graduateinstitute.ch/record/292694/files/GMPRS_N11_2015.pdf

International Organization for Migration (IOM). (2018). Private Sector. Web: https://www.iom.int/private-sector

Immigration, Refugees and Citizenship Canada (IRCC). (2016). IRCC Evaluation of Local Immigration Partnerships. Government of Canada publication for the Pathways to Prosperity Conference, November $30^{\text {th }} 2016$. Web: http://p2pcanada.ca/wpcontent/blogs.dir/1/files/2016/12/David-Kurfurst-p2p-2016-LIPs-Evaluation.pdf

Immigration, Refugees and Citizenship Canada. (2017). Information for Immigration Levels, Settlement and Integration Consultation 2017. Web: https://www.canada.ca/content/dam/ircc/migration/ircc/english/pdf/backgrounder-online- surveyinvitation_en.pdf 
Jayaraman, S. \& Bauder, H. (2013). Niche Employment or Occupational Segmentation? Immigrant Women Working in the Settlement Sector in Germany and Canada. (RCIS Working Paper 2013/3). Toronto: Ryerson Centre for Immigration and Settlement. Web: https://www.ryerson.ca/content/dam/rcis/documents/RCIS WP Jayaraman_No_2014_3.pdf

Karakayali, S., \& Keist, J.O. (2014). Volunteers and asylum-seekers. Forced Migration Review 51, 65-67

Katz, B., Noring., L \& Garrelts, N. (2016). Cities and Refugees- The German Experience. Washington: The Brookings Institution. Web: https://www.brookings.edu/research/cities-and-refugees-thegerman-experience/

Kelly, N. \& Trebilcock, K. (2010). The Making of a Mosaic: A History of Canadian Immigration Policy. Toronto: University of Toronto Press.

Kilbride, K.M. (2009). A Scoping Study on Settlement Services in the City of Toronto: Final Report. Toronto: Centre of Excellence for Research on Immigration and Settlement. Web: http://ceris.ca/wpcontent/uploads/virtuallibrary/Kilbride_2010.pdf

Kilbride, K.M. \& Anisef, P. (2001). To Build on Hope: Overcoming the Challenges Facing Newcomer Youth in Ontario. Toronto: Centre of Excellence for Research on Immigration and Settlement. Web: http://atwork.settlement.org/downloads/Build_On_Hope_Final_Report.pdf

Klages, H., \& Löffler. (1998). New public management in Germany: The implementation process of the New Steering Model. International Review of Administrative Sciences 64, 41-54

Kohlmeier M., Heine, J., Manana S., \& Hecht, H. (2006). 2005 Policy Analysis Report on Migration and Asylum. Bundesamt fur Migration und Fleuchtlinge. Web: http://www.bamf.de/SharedDocs/Anlagen/EN/Publikationen/EMN/Politikberichte/emnpolitikbericht-2005-germany.pdf?_blob=publicationFile

Korntheuer, A., Prichard, P. \& Maehler D. (2017). Structural Context of Refugee Integration in Germany and Canada. Leibnez: GESIS.

Leo, C., \& August, M. (2009). The Multilevel Governance of Immigration and Settlement: Making Deep Federalism Work. Canadian Journal of Political Science 42 (2), 491-510

Lim, A., Lo, L., Siemiatycki, M. \& Doucet, M. (2005). Newcomer Services in the Greater Toronto Area: An Exploration of the Range and Funding Sources of Settlement Services. (CERIS Working Paper No. 35). Toronto: Centre of Excellence for Research on Immigration and Settlement. Web: https://www.researchgate.net/publication/268348837

Lo, L., Wang, S., Anisef, P., Preston, V. \& Basu, R. (2010). Recent Immigrants Awareness of, Use of, and Satisfaction with Settlement Services in the York Region (CERIS Working Paper No.79). Toronto: Centre of Excellence for Research on Immigration and Settlement. Web:http://www.ceris.metropolis.net/Virtual\%20Library/other/CWP79.pdf

Lohr, R. (2003). Socially Integrative Cities- the cooperation and confrontation between urban research and urban policy in Germany. EURA-Eurocities-MRI Conference on European urban 
development, research and policy- on the future of European cohesion policy, Budapest, August $28^{\text {th }}-30^{\text {th }} 2003$. Berlin: Deutschen Instituts fur Urbanistik.

Lowe, S., Richmond T. \& Shields J. (2017). Settling on Austerity: ISAs, Immigrant Communities and Neoliberal Restructuring. Alternate Routes (28), 14-46.

Maletzky, M. (2017). Changing labour migration politics in Germany: an organizational perspective. International Migration 55, 52-68

Mattes, A. (2017). Part of the problem or of the solution? The involvement of religious associations in immigrant integration policy. Austrian Journal of Political Science, 46 (1), 43-57

McGrath, S. \& McGrath, I. (2013). Funding Matters: The Maze of Settlement Funding in Canada and the Impact on Refugee Services. Canadian Journal of Urban Research 22 (1), 1-20.

Meinhardt, A., Lo, L. \& Hyman, I. (2016). Cross-sector Partnerships in the Provision of Services to New Immigrants in Canada: Characteristics, Relevance and Constraints. Human Service Organizations: Management, Leadership and Governance 40, (3), 281-296.

Menz, G. (2011). Stopping, Shaping and Moulding Europe: Two-Level Games, Non-state Actors and the Europeanization of Migration Policies. Journal of Common Market Studies 49 (2), 437-462

Morris, J. (1997). Neo-Liberal Strategies to Cut Costs in Settlement Services: Cost Recovery and Devolution. Refuge 15 (6), 25-26.

Mueller, C. (2006). Integrating Turkish communities: A German dilemma. Population Research and Policy Review 25, 419-441

Mukhtar, M., Dean, J., Wilson, K., Ghassemi, E. \& Wilson, D.H. (2015). "But Many of These Problems are About Funds..." The Challenges Immigrant Settlement Agencies Encounter in a Suburban Setting in Ontario, Canada. International Migration \& Integration (17), 389-408.

Musch, E. (2012). Consultation Structures in German Immigrant Integration Politics: The National Integration Summit and the German Islam Conference. German Politics 21 (1), 73-90

Mwaringa, M.S. (2002). Towards a Framework for Local Responsibility: Taking action to end the current limbo in immigrant settlement- Toronto. Toronto: Maytree. Web: http://www.urbancentre.utoronto.ca/pdfs/elibrary/Maytree_Immigrant-Settlemen.pdf

Nakhaie, Reza. (2018). Service Needs of Immigrants and Refugees. International Migration and Integration, 19. 143-160.

Navaratna, Pradeep. (2014). Resettlement of Government-assisted Refugees in Hamilton, Ontario. Our Diverse Cities 4, ed. Katherine Graham. Toronto: Metropolis, 156-161.

Neudorf, E.G. (2016). Key Informant Perspectives on the Government of Canada's Modernized Approach to Immigrant Settlement. Canadian Ethnic Studies 48 (3), 91-107.

Nijboer, H. (2010). Federal-Provincial Relations on Immigration: Striking the Right Balance. (Unpublished Master's Thesis). University of Toronto, Toronto. 
Neuman, L.W (2006). Social Research Methods: Qualitative and Quantitative Approaches. Boston: Pearson Education, 2006. Print

Papillion, M. (2002). Immigration, Diversity and Social Inclusion in Canada's Cities. (Discussion Paper F/27). Ottawa: Canadian Policy Research Networks. Web: http://rcrpp.org/documents/17246_fr.pdf

Pero, R. (2017). The New Governance of Immigration in Canada: Local Immigration Partnerships and their role in Immigrant Settlement and Integration in Small- and Medium-sized Ontarian Cities. Doctoral Thesis in the Graduate Program of Geography and Planning. Kingston: Queen's University.

Prem, M. (2017). Access to Resettlement Services in Germany: Language Options for Refugees and Asylum-Seekers in Germany. in Structural Context of Refugee Integration in Canada and Germany eds. Annette Korntheuer, Paul Pritchard and Debora B. Maehler. Liebniz: Leibniz Institute for the Social Sciences, 119-127

Reichhold, Stephan. (2010). Do community-based organizations serve the people or the state? A look at community services for newcomers in Quebec. Our Diverse Cities 7, ed. Francoise Armand and Marie McAndew. Toronto: Metropolis, 37-41.

Richmond, T., \& Omidvar, R. (2003). Immigrant Settlement and Social Inclusion in Canada. (Laidlaw Foundation Working Paper Series 1). Toronto: Laidlaw Foundation. Web: http://laidlawfdn.org/wpcontent/ uploads/2014/08/wpsosi_2003_jan_immigrant-settlement.pdf

Richmond, T. \& Shields, J. (2005). NGO-Government Relations and Immigrant Services: Contradictions and Challenges. Journal of International Migration and Integration 6 (3/4), $513-$ 526

Richmond, T. \& Shields, J. (2005). NGO-Government Relations and Immigrant Services: Contradictions and Challenges. Journal of International Migration and Integration 6 (3/4), 513 526.

Rose, J., \& Preston, V. (2017). Canadian Municipalities and Services for Immigrants: A Toronto Case Study. Canadian Journal of Urban Research 26 (1), 29-39.

Russell, C. (2005). An overview of the integrative research review. Progress in Transplantation 15 (1), 813

Sadiq, K. (2004). The Two-Tier Settlement System: A Review of Current Newcomer

Settlement Services in Canada. (CERIS Working Paper 34). Toronto: Centre of Excellence for Research on Immigration and Settlement. Web: https://books1.scholarsportal.info/viewdoc.html?id=25337

Salamon, L., \& Wojciech Sokolowski, S. (2016). Re-conceptualizing the Third Sector. Voluntas 27 (4), 1515-1545

Scherr, A. (2013). The Construction of National Identity in Germany: "Migration Background" as a Political and Scientific Activity (RCIS Working Paper 2013/2). Toronto: Ryerson Centre for Immigration and Settlement. Web: https://www.ryerson.ca/content/dam/rcis/documents/RCIS_WP_Scherr_No_2013_2.pdf 
Schmitter Heisler, B. (1986). Immigrant Settlement and the Structure of Emergent Immigrant Communities in Western Europe. The Annals of the American Academy of Political and Social Science 485, 76-86

Schmidke, O. (2014). "Beyond National Models? Governing Migration and Integration at the regional and local levels in Canada and Germany" Comparative Migration Studies 2, (1), 77-99

Schneider, J. (2012). The Organization of Asylum and Migration Policies in Germany. (German National Contact Point for the European Migration Network Working Paper 25). Berlin: BAMF. Web: https://www.bamf.de/SharedDocs/Anlagen/EN/Publikationen/EMN/Studien/wp25-emnorganisation-asylpolitik.html

Schneider, J., \& Scholten, P. (2015). Consultative Commissions and the Rethinking of Integration Policies in the Netherlands and Germany: The Blok Commission and the Süssmuth Commission Compared. in Integrating Immigrants in Europe eds. Peter Scholten, Han Entzinger, Rinux Penninx, Stijn Verbeek. London: Springer, 77-99

Schönwälder, K., \& Triadafilopoulos., T. (2016). The New Differentialism: Responses to Immigrant Diversity in Germany. German Politics 25 (3), 366-380

Schönwälder, K., \& Söhn, J. (2009). Immigrant Settlement Structures in Germany: General Patterns and Urban Levels of Concentration of Major Groups. Urban Studies 46 (7), 1439-1460

Sen, A. (2004). Elements of a Theory of Human Rights. Philosophy and Public Affairs, 32 (4), 315-356

Sezgin, Z., \& Dijkzeul, D. (2014). Migrant Organizations in Humanitarian Action. Journal of International Migration and Integration 15 (2), 159-177

Shah, Z. (2016). Welcome to Canada: A Critical Examination of the Neoliberal Restructuring of Canada's Model of Settlement Service Deliver. (Unpublished Master's Thesis). Ryerson University, Toronto.

Shields, J. (2004). No Safe Haven: Migrants, Welfare and Markets. (Policy Matters Paper Series No. 7.) Toronto: Centre of Excellence for Research on Immigration and Settlement. Web: http://ceris.ca/wp-content/uploads/virtuallibrary/Shield 2004.pdf

Shields, J., Drolet, J., \& Valenzuela, K. Immigrant Settlement and Integration Services and the Role of Non-Profit Service Providers: A Cross-national Perspective on Trends, Issues and Evidence. (RCIS Working Paper 2016/1). Toronto: Ryerson Centre for Immigration and Settlement. Web: https://www.ryerson.ca/content/dam/rcis/documents/RCIS\%20WP\%202016 01\%20Shields\%20e t\%20al\%20final.pdf

Shields, J. \& Evans, B. (2000). Neoliberal Restructuring and the Third Sector: Reshaping Governance, Civil Society and Local Relations. (RCVS Working Paper Series 1). Toronto: Ryerson Centre for Voluntary Studies. Web: https://www.ryerson.ca/content/dam/cvss/reports/2000\%20v1\%20Neoliberal.pdf

Shields, J. \& Evans, B. (1998). Shrinking the State: Globalization and the "Reform" of Public Administration. Halifax: Fernwood. 
Shields, J., Turegun, A. \& Lowe, S. (2014). Final Report: Settlement and Integration Research Synthesis. Toronto: Toronto: Centre of Excellence for Research on Immigration and Settlement. Web:

http://ceris.ca/wp- content/uploads/2015/01/CERIS-Research-Synthesis-on-SettlementandIntegration.pdf

Shan, H. (2015). Settlement Services in the Training and Education of Immigrants: Toward a Participatory Mode of Governance. New Directions for Adult and Continuing Education $146,19-28$.

Siemiatycki, M. \& Triadafilopoulos, T. (2010). International Perspectives on Immigrant Service Provision. Toronto: Mowat Center for Policy Innovation. Web: https://mowatcentre.ca/wpcontent/uploads/publications/5_international_perspectives_immigratio $\underline{\text { n.pdf }}$

Stasiulus, D., Hughes, C. \& Amery, Z. (2011). From Government to Multilevel Governance of Immigrant Settlement in Ontario's City Regions in Immigrant Settlement Policy in Canadian Municipalities ed. Erin Tolley and Robert Young. Montréal, QC: McGillQueen's University Press, 73-147

Statistics Canada. (2017). Immigration and Ethnocultural Diversity: Key Results from the 2016 Census. Web: https://www150.statcan.gc.ca/n1/daily-quotidien/171025/dq171025b-eng.htm

Süssmuth, R. (2009). The Future of Migration and Integration Policy in Germany. Washington, DC: Migration Policy Institute. Web: https://www.migrationpolicy.org/pubs/TCM-GermanPolicy.pdf

Thränhardt, D. (1989). Patterns of Organization among Different Ethnic Minorities. New German Critique 46, 10-26

Tilson, D. (2010). Best Practices in Settlement Services: Report on the Standing Committee on Citizenship and Immigration. Ottawa: House of Commons Canada, $40^{\text {th }}$ Parliament, $3^{\text {rd }}$ Session. Web: http://olip-plio.ca/wp-content/uploads/2013/03/2010-Standing-Committee-ReportCIC.pdf

Tolley, E. (2011) Who Invited Them To The Party? Federal-Municipal Relations in Immigrant Settlement Policy in Immigrant Settlement Policy in Canadian Municipalities ed. Erin Tolley and Robert Young. Montréal, QC: McGill-Queen's University Press, 3-48

Trudeau, D., \& Veronis, L. (2009). Enacting state restructuring: NGOs as 'translation mechanisms.' Environment and Planning D: Society and Space 27, 1117-1134.

Valenzuela, K., Shields, J. \& Drolet, J. (2018). Settling Immigrants in Neoliberal Times: NGOs and Immigrant Well-being in Comparative Context. Alternate Routes: A Journal of Critical Social Research 29, 65-89.

Wagstyl, S. (2016). Germany sets out plans for migrant integration law. Financial Times, April $14^{\text {th }} 2016$. Web: https://www.ft.com/content/b9682e48-0246-11e6-9cc4-27926f2b110c 
Young, D. (2000). Alternative Models of Government- Nonprofit Sector Relations: Theoretical and International Perspectives. Nonprofit and Voluntary Sector Quarterly 29 (1), 149-172

Yükleyen, A., \& Yurdakul, G. (2011) Islamic Activism and Immigrant Integration: Turkish Organizations in Germany. Immigrants \& Minorities 29, (1), 64-85

Zhu, Y. (2016) Immigration Policy, Settlement Service and Immigrant Mothers in Neoliberal Canada: A Feminist Analysis. Canadian Ethnic Studies 48 (2), 143-156.

Zimmer, A. (1999). Corporatism revisited- the Legacy of History and the German Non-profit Sector. Voluntas 10 (1), 37-49

Zimmer, A., Gartner, J., Priller, E., Rawert, P., Sacße, C., Strachwitz, R., Walz,. R. (2004). The Legacy of Subsidiary: The Nonprofit Sector in Germany. in Future of Civil Society eds. Annette Zimmer and Eckhardt Priller. Weisbaden: Verlag für Sozialwissenschaften, 681-712 